\title{
Article \\ Shedding Lights on Crude Venom from Solitary Foraging Predatory Ant Ectatomma opaciventre: Initial Toxinological Investigation
}

\author{
Lucas Ian Veloso Correia 1,2,*, Fernanda Van Petten de Vasconcelos Azevedo 1,2, Fernanda Gobbi Amorim ${ }^{3}$ (D) \\ Sarah Natalie Cirilo Gimenes ${ }^{1,4}{ }^{D}$, Lorena Polloni ${ }^{1}$, Mariana Alves Pereira Zoia ${ }^{2}$, Mônica Soares Costa ${ }^{1}$, \\ Jéssica Peixoto Rodrigues ${ }^{2}$ (D), Kelly A. Geraldo Yoneyama ${ }^{1}$, Jean Carlos Santos ${ }^{5}$, Eliane Candiani Arantes ${ }^{3}(\mathbb{D}$, \\ Veridiana de Melo Rodrigues ${ }^{1}$, Luiz Ricardo Goulart ${ }^{2}$ and Renata Santos Rodrigues ${ }^{1, *}$
}

Citation: Correia, L.I.V.; Azevedo, F.V.P.d.V.; Amorim, F.G.; Cirilo Gimenes, S.N.; Polloni, L.; Zoia, M.A.P.; Costa, M.S.; Rodrigues, J.P.; Yoneyama, K.A.G.; Santos, J.C.; et al. Shedding Lights on Crude Venom from Solitary Foraging Predatory Ant Ectatomma opaciventre: Initial Toxinological Investigation. Toxins 2022, 14, 37. https://doi.org/ $10.3390 /$ toxins 14010037

Received: 1 December 2021 Accepted: 24 December 2021 Published: 4 January 2022

Publisher's Note: MDPI stays neutral with regard to jurisdictional claims in published maps and institutional affiliations.

Copyright: (C) 2022 by the authors. Licensee MDPI, Basel, Switzerland. This article is an open access article distributed under the terms and conditions of the Creative Commons Attribution (CC BY) license (https:// creativecommons.org/licenses/by/ $4.0 /)$.
1 Laboratory of Biochemistry and Animal Toxins, Institute of Biotechnology, Federal University of Uberlândia, Uberlândia 38408-100, MG, Brazil; fvpetten@yahoo.com (F.V.P.d.V.A.); sarah_gi_menes@hotmail.com (S.N.C.G.); polloni.lorena@gmail.com (L.P.); monicacosta.farma@gmail.com (M.S.C.); kellyagy@gmail.com (K.A.G.Y.); vmravila@hotmail.com (V.d.M.R.)

2 Laboratory of Nanobiotechnology Institute of Biotechnology, Federal University of Uberlândia, Uberlândia 38408-100, MG, Brazil; marianazoia@hotmail.com (M.A.P.Z.); jessica.prt@hotmail.com (J.P.R.); goulartlr@gmail.com (L.R.G.)

3 Laboratory of Animal Toxins, Faculty of Pharmaceutical Sciences of Ribeirão Preto, Universidade de São Paulo, Ribeirão Preto 14040-900, SP, Brazil; fernandagamorim@gmail.com (F.G.A.); ecabraga@fcfrp.usp.br (E.C.A.)

4 Laboratory of Immunopathology, Institute Butantan, São Paulo 05503-900, SP, Brazil

5 Department of Ecology, Institute of Biology, Federal University of Sergipe, São Cristovão 49060-108, SE, Brazil; jcsantosbio@gmail.com

* Correspondence: lucasian.veloso@gmail.com (L.I.V.C.); renata.rodrigues@ufu.br (R.S.R.); Tel.: +55-34-3225-8436 (R.S.R.)

Abstract: Some species of primitive predatory ants, despite living in a colony, exercise their hunting collection strategy individually; their venom is painful, paralyzing, digestive, and lethal for their prey, yet the toxins responsible for these effects are poorly known. Ectatomma opaciventre is a previously unrecorded solitary hunting ant from the Brazilian Cerrado. To overcome this hindrance, the present study performed the in vitro enzymatic, biochemical, and biological activities of E. opaciventre to better understand the properties of this venom. Its venom showed several proteins with masses ranging from 1-116 kDa, highlighting the complexity of this venom. Compounds with high enzymatic activity were described, elucidating different enzyme classes present in the venom, with the presence of the first L-amino acid oxidase in Hymenoptera venoms being reported. Its crude venom contributes to a state of blood incoagulability, acting on primary hemostasis, inhibiting collagen-induced platelet aggregation, and operating on the fibrinolysis of loose red clots. Furthermore, the E. opaciventre venom preferentially induced cytotoxic effects on lung cancer cell lines and three different species of Leishmania. These data shed a comprehensive portrait of enzymatic components, biochemical and biological effects in vitro, opening perspectives for bio-pharmacological application of E. opaciventre venom molecules.

Keywords: ant venom; Ectatomma opaciventre; enzymatic assays; antitumoral activity; lung cancer; antiparasitic effects; Leishmania; hyaluronidase; L-amino acid oxidase

Key Contribution: This is the pioneer report about venom from the solitary foraging predatory ant species Ectatomma opaciventre. The first L-amino acid oxidase from Hymenoptera venoms was revealed by E. opaciventre venom. E. opaciventre shows a selective cytotoxicity against lung cell cancer, Leishmania infatum, Leishmania amazonensis, and Leishmania brasiliensis. 


\section{Introduction}

Insects are invertebrates with a wide variety of defense mechanisms, which is why they have managed to occupy the most diverse terrestrial environments [1]. Ants are aculeated Hymenoptera, as they have an inoculation device (stinger), in addition to the corresponding secretory glands, where the venom is produced, stored in a reservoir connected to the inoculation device [2,3]. From 21 subfamilies of Formicidae, five lost their sting in the evolutionary process, through changes in the morphology of the terminal region of the gaster (such as the acidopore of the subfamily Formicinae, used to project a toxic composed basically of formic acid and hydrocarbons). Thus, 16 subfamilies retained the ability to use their venom to search for food by subduing their prey [4]. This foraging and predation habit is exercised collectively or individually, with the latter group standing out for having a sufficiently powerful venom to incapacitate their prey [5].

Although ant venoms are richly diverse in toxins, bioactive compounds, alkaloids, proteins, and peptides [4,6-8], knowledge about the toxinology of these animals remains limited or even largely unknown due extensively to the number of species. The lack of information about the effects derived from crude venom stands out in this scenario, as such understanding is important from a medical point of view in cases of allergies, envenoming, and anaphylaxis, as well as from the perspective of these effects in the process of drug discovery [9-11]; this is exemplified by the most famous success of a toxin that bioinspired the design of Captopril, from the observation of the hypotensive effect of the bite by the Brazilian snake Bothrops jararaca [11].

This lack of data in ants is mainly due to the limited amount of venom that can be obtained from a single ant as well as the laborious dissection and extraction of the venom, especially in solitary foraging ants, as the capture is completed individually, instead of by entire colonies, like ants as previously reported in the Solenopsis genus [12]. Despite the limitations, interest in ant venoms has increased in recent years with interesting actions being reported as antiparasitic, antimicrobial, and antinociceptive action on Dinoponera quadriceps venom [13-15], insecticidal activity on Manica rubida venom [16], and modulation of immune response and redox balance in vivo by the Brachyponera sennaarensis venom [17]

The genus Ectatomma (Hymenoptera: Formicidae: Ectatomminae) has 14 described species present in the Neotropical region and, despite living in colonies, they exercise their foraging and predation solitarily [18]. In 1994, Arseniev et al. described for the first time a component from Ectatomma tuberculatum venom, ectatomin, a hetorodimeric neuropeptide acting on calcium channels and forming pores in the membrane cells $[19,20]$. Twenty years later, synthetic peptides homologous to Ectatomma quadridens [homonym replaced by Ectatomma brunneum] venom showed antimicrobial and cytotoxic activity against tumor cells [21]. Thus, solitary foraging ants, mainly of the Ectatomma genus, present a large field of research due to the lack of studies on the characterization of the crude venom and the low number of isolated components. Ectatomma opaciventre is a relatively large predatory ant $(1.5 \mathrm{~cm})$ that exhibits well-developed mandibles and a stinger apparatus; its geographic distribution covers some countries in South America, Brazil being the largest record of the presence of the species [18].

Given the above, the characterization of the venom of ant species can contribute to a better understanding of the evolution of ant and Hymenoptera toxins, as well as the variability of the venoms within the venomous ant genera and subfamilies, toxic potential to man, and important biological tool potential in drug discovery. Herein, we intend to better understand the venom of the solitary foraging ants E. opaciventre, through a descriptive approach of their biochemical effects, the activity and description of the enzyme classes present in the venom, and the biotechnological potentials and therapeutic applications of the venom. 


\section{Results}

2.1. Analysis of Peptides, Proteins, and Zymography Profile in Polyacrylamide Gel from E. opaciventre Venom

The ant venoms showed great variability in their composition, with a large protein range from $1 \mathrm{kDa}$ to $114 \mathrm{kDa}$. SDS-PAGE analysis demonstrated the diversity of components among proteins and peptides in E. opaciventre venom, with intense bands of peptides (Figure 1A) and proteins (Figure 1B). Figure 1A shows some differences between reduced and non-reduced profiles, especially at 6.5 and $3.49 \mathrm{kDa}$. These results suggest the presence of proteins in different state of oligomerization. The non-reduced sample shows an intense band around $6.5 \mathrm{kDa}$ and less intensity on the reduced sample at the same molecular mass; the opposite can be observed around $3.49 \mathrm{kDa}$, where the reduced sample has a more intense band and less intensity on the non-reduced sample. In this context, we can exemplify the presence of peptides on dimers conformation on the venom composition.
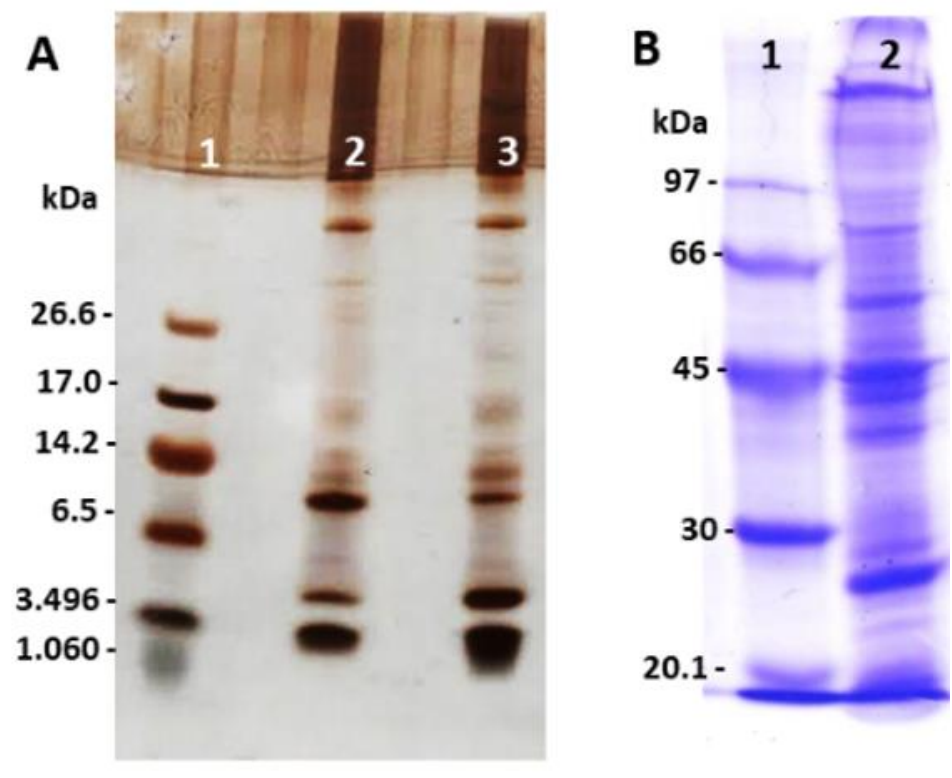

Figure 1. Protein profile by SDS-PAGE. (A) SDS-PAGE (21\%) stained with silver. (1) Molecular Mass Standard. (2) $40 \mu \mathrm{g}$ of the crude venom of E. opaciventre (non-reduced). (3) $40 \mu \mathrm{g}$ of the crude venom of E. opaciventre (reduced by $\beta$-mercaptoethanol). (B) SDS-PAGE (12.5\%) stained with comassie blue. (1) Molecular Mass Standard. (2) $40 \mu \mathrm{g}$ of the crude venom of E. opaciventre under reduced conditions.

When we analyzed the proteolytic capacity of venom proteins, the zymography method was able to associate the nature and molecular mass of the diverse proteins present in the venom, highlighted by their intense enzymatic performance. Gelatin and hyaluronan were also used for copolymerization of the acrylamide gel to show the enzymatic activity in a different substrate. The results showed a band of approximately $38 \mathrm{kDa}$ evidencing high hyaluronidase activity (Figure 2A), while a proteolytic activity was observed in the $40 \mathrm{kDa}$ range when gelatin was topped as a substrate (Figure $2 \mathrm{~B}$ ). All these results together showed a rich variety of proteolytic compounds on E. opaciventre venom.

\subsection{Detection of Enzyme Classes Contained in the E. opaciventre Crude Venom and Quantitative Evaluation of Activity}

Due to the large diversity of the protein bands on SDS-PAGE and the identification of the enzymatic activity of some components of the venom, showed in Figure 2, a deeper characterization of these components was performed. Hyaluronidase activity demonstrated that $1.12 \mu \mathrm{g}$ were required to degrade $50 \%$ of the hyaluronan present in the medium, thereby obtaining $892.65 \mathrm{UTR} / \mathrm{mg}$ of specific activity (Figure 3A). The enzymes present in the venom showed a preference for degrading hyaluronan, followed by chondroitin sulfate 
A, C, and B, hydrolyzing about $98 \%, 55 \%, 19 \%$, and $12 \%$ of the substrates contained in the medium, respectively (Figure 3B).
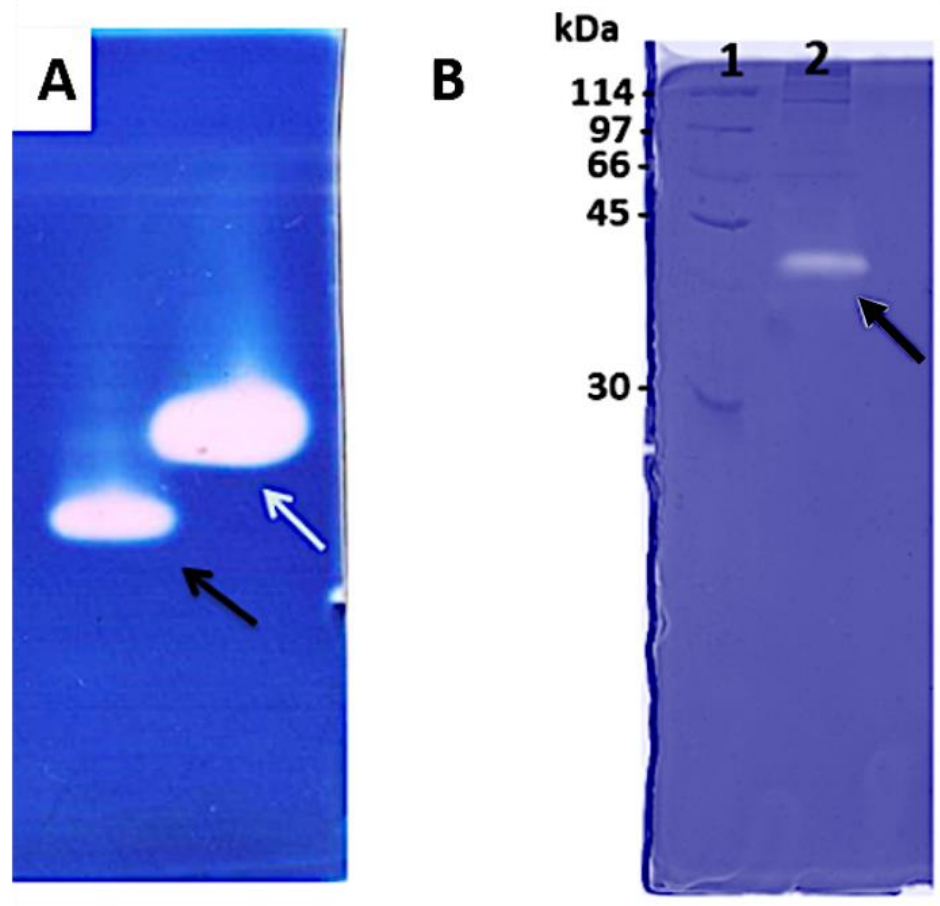

Figure 2. Zymography assay. (A) Acrylamide-hyaluronan zymography gel from the crude venom of E. opaciventre, analyzed under non-reduced conditions. (1) $40 \mu \mathrm{g}$ of the crude venom of E. opaciventre; the black arrow shows the protein activity around $38 \mathrm{KDa}$. (2) Sample of scorpion Tityus serrulatus as a positive control; the white arrow shows the protein activity around $40 \mathrm{KDa}$. (B) Acrylamide gelatin-zymogram under non-reduced conditions of the crude venom of E. opaciventre. (1) Molecular Mass Standard. (2) $10 \mu \mathrm{g}$ of the crude venom of E. opaciventre.

A

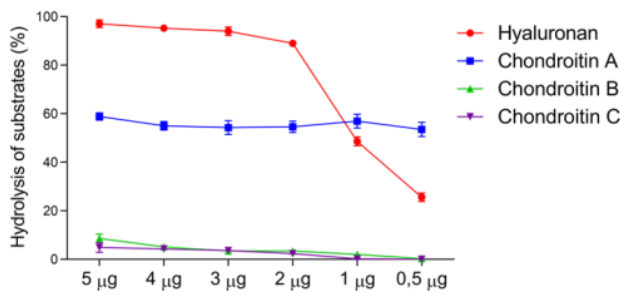

B

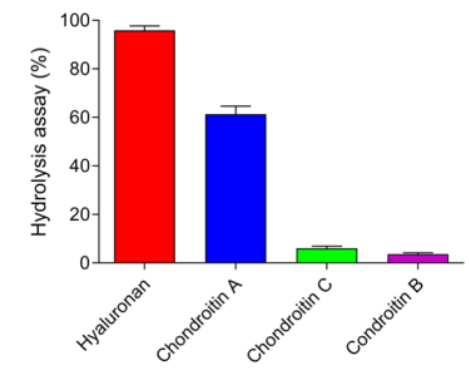

Figure 3. Hyaluronidase activity profile. (A) Turbidimetric activity of the different concentration of crude venom, from E. opaciventre on different substrates that were incubated for $30 \mathrm{~min}$ in $200 \mathrm{~mm}$ acetate buffer, $150 \mathrm{~mm}$ sodium chloride $\mathrm{pH}$. The hydrolysis reaction was quenched with $5 \%$ BCTA and $4 \mathrm{NaOH} \%(w / v)$. The activity was read at $400 \mathrm{~nm}$ and expressed as a percentage. All data are expressed as mean \pm S.E.M and procedures were carried out in triplicate. (B) The preferential degradation profile of hyaluronidases from E. opaciventre venom.

The azocaseinolytic activity of E. opaciventre crude venom was of $184 \mathrm{U} / \mathrm{mg}$ (Figure 4A). This value was similar to the positive control known by higher azocaseinolytic activity, the Metalloproteinase Bothropoidin from Bothrops pauloensis venom [22]. In addition, to investigate the effect of inhibitory agents on the proteolytic activity of the proteins' venom, we performed the azocaseinolytic activity after venom incubation with different chemical agents (Figure 4B). When we analyzed all inhibitors tested, the 1,10-phenanthroline and 
Aprotinin were able to reduce the venom activity on the degradation of the substrate and, in a lower capacity, the Pepstatin A. The 1,10-phenantroline showed maximum inhibition of $55 \%$, followed by Aprotinin (41\%), PMSF (35\%), EGTA (27\%), EDTA (17\%), and Pepstatin A $(16 \%)$, when compared to the activity of the crude venom (positive control). The azocasein substrate assay was also performed in the presence of divalent cations $\left(\mathrm{Ca}^{2+}, \mathrm{Mg}^{2+}, \mathrm{Zn}^{2+}\right.$, $\mathrm{Cu}^{2+}, \mathrm{Hg}^{2+}$ and $\mathrm{Ba}^{2+}$ ). Our results showed that $\mathrm{Ca}^{2+}$ and $\mathrm{Zn}^{2+}$ were able to slightly increase the proteolytic activity, with $\mathrm{Ca}^{2+}$ being the most active. These results could suggest a higher presence of enzymes $\mathrm{Ca}^{2+}$ and $\mathrm{Zn}^{2+}$, depending (Figure $4 \mathrm{C}$ ). However, the $\mathrm{Hg}^{2+}$ and $\mathrm{Ba}^{2+}$ caused a stronger reduction in the proteolysis of the substrate, which suggests a possible enzymatic inhibition due to the competition of ions.

A

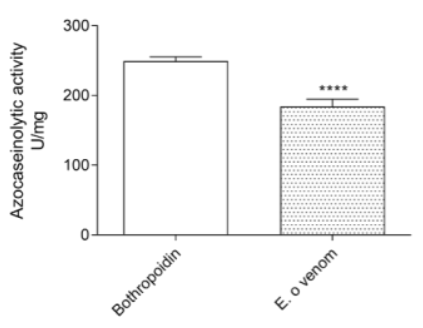

B

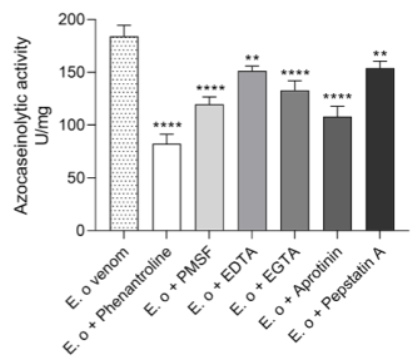

C

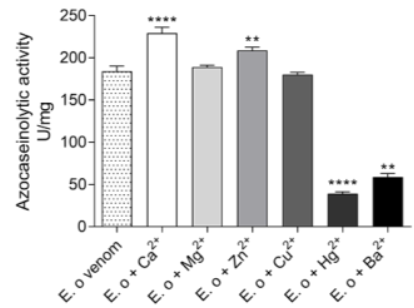

Figure 4. Protease characterization assays. (A) Proteolytic activity of the crude venom on azocasein; $5 \mu \mathrm{g}$ of E. opaciventre ant venom and $5 \mu \mathrm{g}$ of Bothropoidin, a metalloprotease purified from Bothrops pauloensis venom (positive control), incubated for $30 \mathrm{~min}$ at $37^{\circ} \mathrm{C}$. (B) Influence of different inhibitors at a concentration of $10 \mathrm{mM}$, previously incubated with $5 \mu \mathrm{g}$ of E. opaciventre ant venom for $30 \mathrm{~min}$. (C) Influence of different divalent cations at a concentration of $10 \mathrm{mM}$, previously incubated with $5 \mu \mathrm{g}$ of E. opaciventre ant venom for $30 \mathrm{~min}$. The reaction was quenched with addition of $20 \%$ trichloroacetic acid $(v / v)$. The activity was read at $405 \mathrm{~nm}$ and expressed as $\mathrm{U} / \mathrm{mg}$. All data are expressed as mean \pm S.E.M and procedures were carried out in triplicate. Statistically significant differences in relation to control (E. opaciventre venom). ${ }^{* *}(p \leq 0.01)$ and ${ }^{* * * *}(p \leq 0.0001)$.

Following the functional characterization, the phospholipase activity was also performed by the capability of hydrolysis of phospholipids through egg yolk methodology. The halos generated by the indirect activity in agar containing egg yolk for $24 \mathrm{~h}$ of incubation with the venom were $2.8 \mathrm{~cm}$, thus demonstrating a high phospholipase activity (data not shown). The indirect activity does not show the specific phospholipase activity. In order to evaluate the specific activity of phospholipase present on E. opaciventre venom, we also investigated the substrate hydrolysis assay, a direct phospholipase $\mathrm{A}_{2}$ activity. This assay was performed by a $\mathrm{pH}$ meter, and the value of E. opaciventre venom activity determined was $222 \mathrm{mEqNaOH} / \mathrm{mg} / \mathrm{min}$ (Figure 5). In comparison with the positive control, a phospholipase $A_{2}$ isolated from B. pauloensis with an intense enzymatic activity [23], the E. opaciventre showed a greater phospholipase activity. These results suggest the presence of Phospholipase $\mathrm{A}_{2}$, in an active state known as Asp-49 Phospholipase $\mathrm{A}_{2}$. 


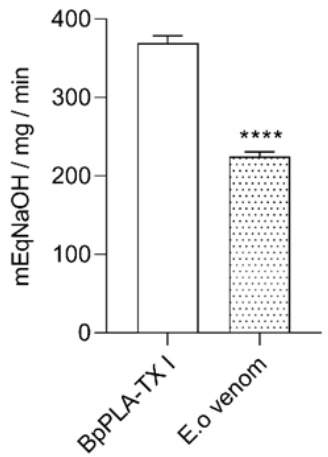

Figure 5. Phospholipase detection. Hydrolysis of phospholipids by the action of $5 \mu \mathrm{g}$ of crude venom from E. opaciventre and $5 \mu \mathrm{g}$ of BpPLA 2 TX-I (positive control). Phospholipase activity was monitored with a $\mathrm{pH}$ meter for $3 \mathrm{~min}$. The activity was expressed in $\mathrm{mEqNaOH} / \mathrm{mg} / \mathrm{min}$. Data show the mean \pm standard deviation (S.D.) Statistically significant differences in relation to control (BpPLA 2 -TXI). $* * * *(p \leq 0.0001)$.

Going forward on E. opaciventre venom characterization, we also performed tests to investigate the presence of L-amino acid oxidases (LAAOs). LAAOs is an important group of toxins mainly described in snake venom. Our group has been working on snake venom characterization and described the presence of LAAOs in different snake venom. Using this background of knowledge, we used L-amino acids as a substrate for oxidative determination to determine the presence of LAAOs on E. opaciventre venom (Table 1). In this context, our results showed a maximum activity of $384.18 \mathrm{U} / \mathrm{mg}$ for serine and a minimum activity of $153.2 \mathrm{U} / \mathrm{mg}$ for asparagine, as well as the average value of $310.43 \mathrm{U} / \mathrm{mg}$ for Valine, $290.05 \mathrm{U} / \mathrm{mg}$ for Glutamine, $259.49 \mathrm{U} / \mathrm{mg}$ for Alanine, and $161.48 \mathrm{U} / \mathrm{mg}$ for Arginine. When we compared these results with data collected before by our group from B. pauloensis venom, the E. opaciventre venom showed higher activity, especially for Serine, which had no activity on snake venom, Valine with $110 \mathrm{U} / \mathrm{mg}$, Glutamine with $140 \mathrm{U} / \mathrm{mg}$, Alanine with $60 \mathrm{U} / \mathrm{mg}$, and $340 \mathrm{U} / \mathrm{mg}$ for Arginine [24]. The function of LAAOs on ant venom remain uncertain; however, our data suggest, at this point, a rich composition of LAAOs with intense activity. Moreover, all enzymatic description together highlights the large variability of venom components present in E. opaciventre venom.

Table 1. L-amino acid oxidase performance. Activity of E. opaciventre on deamination of L-amino acid. $5 \mu \mathrm{g}$ of crude venom incubated with different L-amino acid for $1 \mathrm{~h}$. The reaction was stopped with acid citric $10 \%(v / v)$. One unit $(1 \mathrm{U})$ of enzyme activity was defined as the amount of enzyme able to produce $1 \mathrm{mmol}$ of hydrogen peroxide/min.

\begin{tabular}{cc}
\hline Amino Acids & E. opaciventre \\
\hline Serine & 384.18 \\
Valine & 310.43 \\
Glutamine & 290.05 \\
Alanine & 259.49 \\
Arginine & 161.48 \\
Asparagine & 153.2 \\
\hline
\end{tabular}

\subsection{Evaluation of Effects upon Biochemical Parameters Por E. opaciventre Venom}

As we showed before, E. opaciventre venom has a pronounced proteolytic enzyme content that can act on hemostasis parameters. In this context, we have performed some of the key assays by which these enzymes can operate. The venom did not exert fibrinogenolytic activity when incubated at different concentrations with bovine fibrinogen for $2 \mathrm{~h}$, verified by SDS-PAGE (data not shown); likewise, when evaluated, the venom was not able to coagulate the plasma in a time less than $240 \mathrm{~s}$ (data not shown). All information suggests that the E. opaciventre venom has no effect on hemostasis disorder. However, the E. opaciventre 
venom performed a remarkable action by degrading about $50 \%$ of the spontaneous clots with 48 h of incubation (Figure 6). Even though, when we compared with the positive control Bothrops pauloensis venom (described as a potent thrombolytic venom), our results showed a reasonable thrombolytic. This result was important to suggest a great capacity and potential properties of thrombolysis agent.

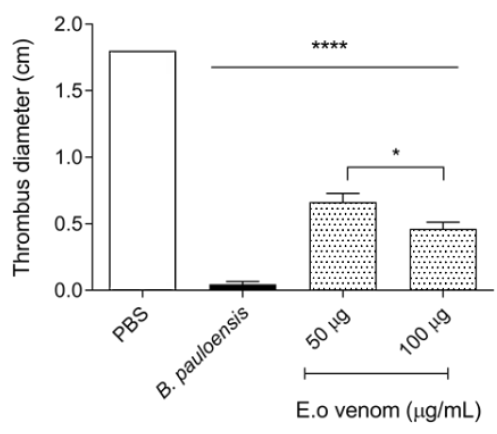

Figure 6. Thrombolytic activity on red clots incubated at $37^{\circ} \mathrm{C}$ for $48 \mathrm{~h}$. The samples of E. opaciventre venom were prepared in phosphate buffered saline (PBS). As controls, $50 \mu \mathrm{g}$ of the Bothrops pauloensis snake venom was used. Data show the mean \pm standard deviation (S.D.) Statistically significant differences in relation to control, positive control by B. pauloensis venom, and phosphate saline buffer as negative control ${ }^{*}(p \leq 0.05)$ and ${ }^{* * * *}(p \leq 0.0001)$.

\subsection{Inhibition of Platelet Aggregation by E. opaciventre Venom}

Following the functional characterization, we investigated the capacity to inhibit the platelet aggregation. Platelets play a key role in primary hemostasis by contributing to the membrane receptors that facilitate and amplify the localized activity of blood clotting factors. This assay characterizes the interference of E. opaciventre crude venom $(30 \mu \mathrm{g})$ in platelet aggregation induced by agonists (ADP, collagen and epinephrine) (Figure 7). The results showed that crude venom strongly inhibits collagen-induced aggregation in $81.4 \%$ (Figure 7A), when compared to ADP 12.5\% (Figure 7B) and epinephrine 1.22\% (Figure 7C). When evaluated for aggregation with platelets previously treated for 20 min with the crude venom, the data reveal an inhibition of $94.19 \%$ when mediated by collagen, followed by $45.56 \%$ by epinephrine and $43.25 \%$ by ADP.

\subsection{Bioprospecting Characterization}

\subsubsection{Evaluation of the Toxicity by E. opaciventre Venom on Lung Cancer Cells}

After all functional characterization and the greatest variability of protein compounds on Ectatomma opaciventre venom, we started an investigation into the potential presence of biomolecules for bioprospection. Since the discovery and production of biomimetic drugs from animal toxins, great attention has been shown to these natural libraries of bioactive molecules in the bioprospecting scenario. In this context, Ectatomma opaciventre venom demonstrated cytotoxicity against A549 cells (Figure 8) via an MTT assay. The venom was able to reduce the cell viability in a concentration-dependent manner, inducing death at a range of approximately $83 \%$ of the highest concentration tested $(100 \mu \mathrm{g} / \mathrm{mL})$. It is important to highlight that the venom did not significantly affect the death of a non-tumorigenic bronchus cell lineage, BEAS-2B, suggesting a specific action on tumorigenic cells (A549). 
A

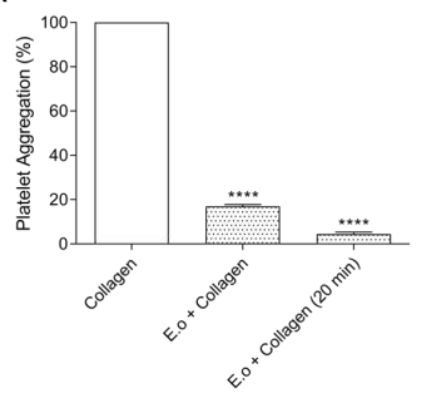

B

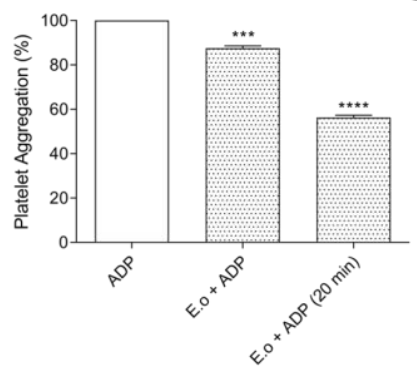

C

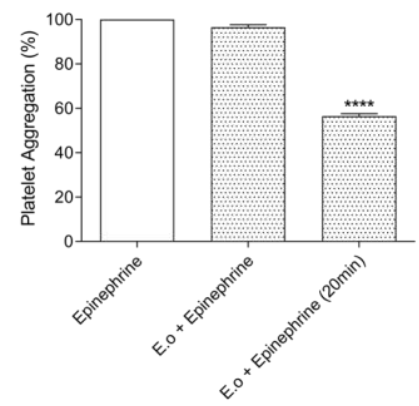

Figure 7. Effects of E. opaciventre crude venom on platelet aggregation. Activation of platelet aggregation (3-4 $\left.\times 10^{5} / \mu \mathrm{L}\right)$ induced by different agonists: adenosine diphosphate, ADP (20 mm); Collagen $(100 \mu \mathrm{g} / \mathrm{mL})$ and Epinephrine $(300 \mu \mathrm{M} / \mathrm{L})$. Platelet aggregation was recorded for $10 \mathrm{~min}$ in AggRAM platelet aggregation system with four-channel laser optics (Helena Laboratories, TX, USA) adding the agonist and the venom simultaneously at the time of testing or pre-treating the platelet solution for $20 \mathrm{~min}$ with the E. opaciventre venom. A representative graph of platelet aggregation activity. (A) Collagen $(100 \mu \mathrm{g} / \mathrm{mL})$. (B) Adenosine diphosphate, ADP (20 mm). (C) Epinephrine $(300 \mu \mathrm{M} / \mathrm{L}$. Statistically significant differences regarding ADP, Collagen, and Epinephrine as positive control. All data are expressed as mean \pm S.E.M and procedures were carried out in triplicate; statistically significant, ${ }^{* * *}(p \leq 0.001)$ and ${ }^{* * *}(p \leq 0.0001)$, treatments compared to control.

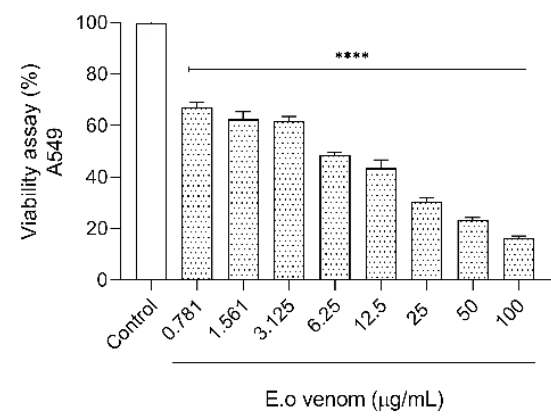

B

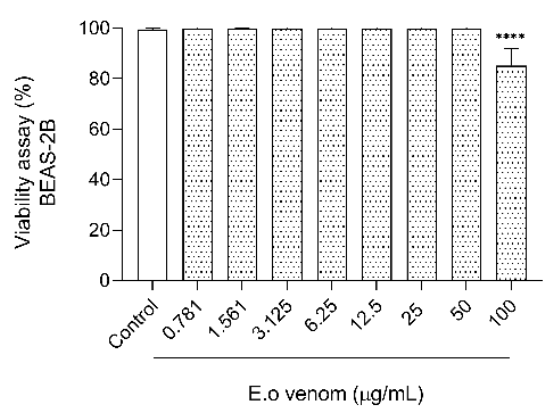

Figure 8. Graphic of viability of tumorigenic and non-tumorigenic cell lines. Cells were cultured in 96-well plates in the absence (control) or presence of different concentrations of the E. opaciventre venom. (A) Effects on Lung Cancer (A549) cell viability induced by E. opaciventre venom. (B) Graph represents the viability of Epithelial Lung (BEAS-2B) cell lineage treated with E. opaciventre venom. The viability is analyzed by an MTT assay. Data show the mean \pm standard deviation (S.D.). Statistically significant difference ${ }^{* * *}(p<0.001)$ compared with control (BEAS-2B).

\subsubsection{Cytotoxic Effect of E. opaciventre Venom on Promastigote Forms of Leishmania}

Going forward with bioprospecting characterization, we performed the cytotoxic assay on promastigote forms of Leishmania. The treatment of promastigote with the E. opaciventre venom showed significant inhibition in viability of parasites. The data obtained at $72 \mathrm{~h}$ allowed us to estimate an $\mathrm{IC}_{50}$ of $50.98 \mu \mathrm{g} / \mathrm{mL}$ to L. braziliensis, $28.00 \mu \mathrm{g} / \mathrm{mL}$ to L. amazonensis, and $22.30 \mu \mathrm{g} / \mathrm{mL}$ to L. infantum. We also observed that the morphological alterations on treated parasites were a rounded and unusual cell body, with loss of membrane integrity, corroborated by $100 \%$ parasite death when treated with the highest dose against L. infantum, 96.6\% against L. braziliensis, and 95.1\% against L. amazonensis (Figure 9). To enhance the bioprospecting properties of E. opaciventre venom, we verified the potential cytotoxicity on macrophage cells. Bone marrow-derived macrophage (BMDM) cells were used as a control, since they are the main cell line involved on the parasitic infection pathway. Thus, when compared with BMDM cells, the E. opaciventre venom did not evoke a significant toxic response, triggering a decrease in viability of around $10 \%$ at the high concentration 
tested (Figure 9). These results suggest a preference action for promastigote forms rather than normal cells, which is a crucial point for developing new drug designs.

A

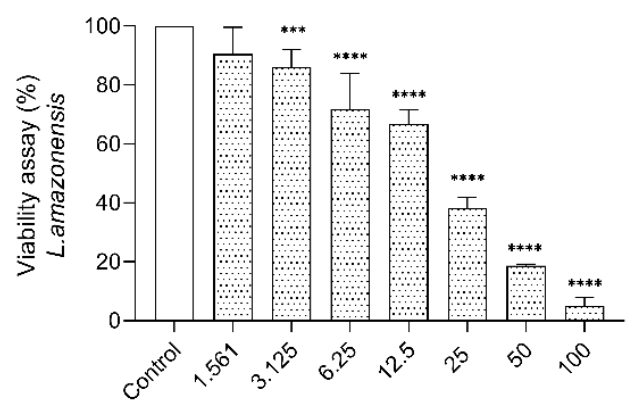

C

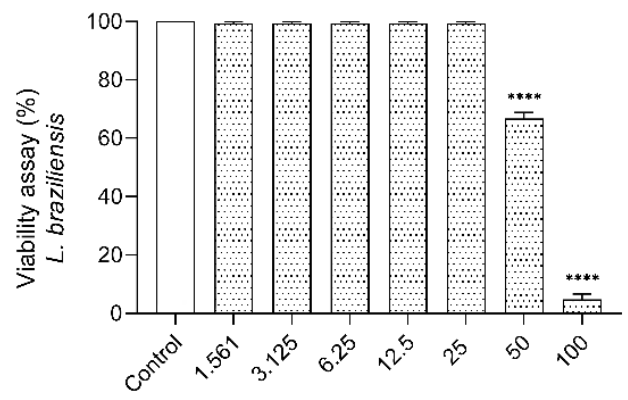

B

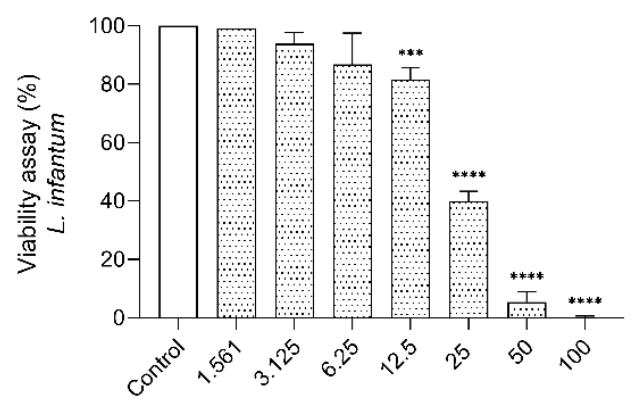

D

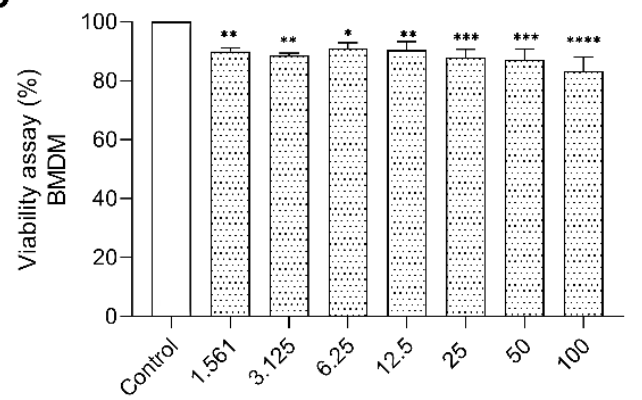

Figure 9. Antiparasitic Assay. Effects of E. opaciventre ant venom on the viability of different parasites. The viability of parasites cultured for $72 \mathrm{~h}$ in the presence of different concentrations of the venom and absence (control), analyzed by the MTT colorimetric method. (A) Viability on the promastigote form of L. amazonensis treated with E. opaciventre venom. (B) L. braziliensis viability treated with E. opaciventre venom. (C) Analysis of L. infantum viability after treatment with $E$. opaciventre venom. (D) BMDM cell viability after exposure to E. opaciventre venom. Data show the mean \pm standard deviation (S.D.). Statistically significant difference ${ }^{*}(p<0.05),{ }^{* *}(p<0.01),{ }^{* * *}(p<0.001)$ and **** $(p \leq 0.0001)$ compared with control.

\section{Discussion}

Many of the venoms from the most diverse animal species are a complex mixture of bioactive components, such as proteins, peptides, and organic and inorganic components such as biogenic amines and neurotransmitters [4,6-8]. In the animal kingdom, venom has several functions, the most important are defense against predators and capture of prey [25]. Solitary foraging ants need venom sufficiently powerful to individually deal with the defense and capture of their prey, making their venom an interesting target for study $[5,18]$.

Despite advances promoted by venomics (represented by mass spectrometry in proteomic and peptidomic studies and by molecular biology in transcriptomic approaches to venoms) allowing for a deep knowledge of the ant venoms' composition [26-29], the effects of crude venom or isolated toxins are untapped, fostering different hypotheses about the role of venom, the biochemical, biological, and clinical implications, and in the process of drug discovery $[7,8,11]$. For example, several studies have already approached ant venom through venomics tools $[28,30-35]$, and many reviews have highlighted the importance of the allergic response to envenomation by ants [10,36-39]. Nevertheless, this significant biomedical interest remained poorly characterized until 2018, when Zamith-Miranda and collaborators cast a new light on the mechanisms of the allergenic process mediated by a proteinaceous extract from fire ants [40].

Due to the aforementioned, it is necessary whenever possible, given the difficulties of obtaining a sample (already highlighted) and the huge number of species, to carry out 
studies that provide knowledge not only in "omic" manner, but also regarding the function of crude venom and toxins. This comprehensive portrait will enable a holistic knowledge in the toxinological, ecological, evolutionary, and clinical aspects of ants, as well as providing new insights into bioprospection of biomolecules with potential biopharmacological action.

\subsection{Evaluation of Enzymatic Profile from E. opaciventre Venom}

This is the first exploratory study of the biological action of the solitary predator ant Ectatomma opaciventre venom. Analysis of the electrophoretic profile of the venom showed intense bands of low molecular weight components in the range of $1.5 \mathrm{kDa}, 4.5 \mathrm{kDa}$ and $10 \mathrm{kDa}$. Some differences between the molecular signature between the reduced and non-reduced profile by $\beta$-mercaptoethanol, which occupies the presence of dimeric polypeptides in the venom of Ectatomma opaciventre. It is already known that polypeptides found in ant venoms can be structurally classified as linear, dimeric, and inhibitors of the cystine node (ICK-like) [4].

Hymenopteran venoms contain a large diversity of peptides that constitute a predominant class of toxins in ant venoms $[4,21,41,42]$. Despite being extensively studied for their biological activity, the envenoming effects of ant peptides are still poorly understood. Ectatomin, a neuropeptide isolated from Ectatomma tuberculatum venom, has a molecular mass of $7.8 \mathrm{kDa}$ and is composed of two subunits held together by a bound disulfide. Ectatomin is a potent inhibitor of calcium channels, acting in isolated rat myocardium, as reported by Pluzhni-kov et al. (1999) [19,20,43]; our data revealed the presence of dimeric peptides by SDS-PAGE analysis of the venom of E. opaciventre. Regarding the components of high molecular mass, our results revealed intense protein bands distributed from $14.4 \mathrm{kDa}$ to $114 \mathrm{kDa}$. The knowledge accumulated in the field of toxinology to date about toxins from animal venoms, allows us to suggest the presence of some classes of enzymes based on their molecular mass, combined with the functional characterization performed [6,7,44]. The enzymatic characterization pointed out some of the main classes of enzymes from animal venoms present in E. opaciventre venom.

First, two distinct enzymatic activities were demonstrated by the E. opaciventre venom using a zymogram technique co-polymerized with hyaluronan and gelatin, thus enabling the presence of hyaluronidases and proteases in the venom. Moreover, when we combined the results from the influence of different divalent cations on enzymatic activity, we can also suggest the presence of an ion-dependent enzyme, such as metalloproteinase. In agreement with our results, several proteases were identified and characterized in the crude venom of the ant Odontomachus bauri by collagen zymogram assay [45]. In addition, hyaluronidases from invertebrate and vertebrate venom animals were already described using polyacrylamide gel co-polymerized with hyaluronan [46], which corroborate with our data and conclusions.

\subsubsection{Hyaluronidases}

Hyaluronidases are the group of enzymes that preferentially cleave hyaluronan, also being capable of degrading chondroitin and chondroitin sulfate to a lesser degree. These glycosaminoglycans are present in the extracellular matrix (ECM) of different organisms [44]. Thus, when degrading the components of the interstitial matrix, the animal venom hyaluronidases are considered spreading factors, aiding and enhancing the diffusion of toxins in the tissue/organism of the prey/victim. In Hymenoptera, these enzymes also can act as allergens, being able to induce anaphylactic shock mediated by IgE, which can be fatal in some cases $[30,44,47,48]$. In E. opaciventre, after detecting the presence of this class of enzymes by zymogram, we analyzed the specific activity under hyaluronan substrate, but also of the main chondroitin present in the ECM. This approach allowed us not only to quantify the specific activity, but also to characterize the degradation profile of the hyaluronidases contained in the venom, highlighting the potency of this class of enzymes.

The presence of hyaluronidases has already been reported in the genome of Solenopis invicta [49] and Saltator harpegnatos [50] species; at the protein level, hyaluronidase frag- 
ments were detected by bottom-up proteomic techniques in the Dinoponera quadriceps [51] and Solenopsis invicta [52] venoms and top-down in the Pachycondila striata [53] and Paraponera clavata $[30,31]$ venoms. The hyaluronidase activity has already been registered in the venoms of Pogonomyrmex baldius, Ectatomma tubeculatum, and Odontomachus haematodus [54]; unfortunately, the protocol differences between them make it impossible to compare the activity quantitatively. Meanwhile, the hyaluronidase activity of the E. opaciventre venom was 892.65 UTR/mg, which is six times more active than the enzyme from Crotalus durrissus terrificus venom that hydrolyzes hyaluronan, following the same experimental procedure [55], which emphasizes the effectiveness of this enzyme class on venom composition. It is important to highlight that our study was the first to trace a hyaluronan degradation profile of ant venoms, increasing the knowledge of this enzyme class in ant venom species.

\subsubsection{Proteases}

In general, venom proteases are involved in processes of necrosis, inflammation, edema, tissue damage, disturbance of the hemostatic system, modulation of defense mechanisms, and in the spread of venom in victims/prey. Classically, proteases are also credited with the biological role of initiating pre-digestion as well as for their ability to cleave peptide bonds, thus making prey more digestible $[52,56]$. The presence of metalloprotease in the venom of Sonenopsis invicta has been reported by proteomic approaches [52]. Schimidt et al. reported very high proteolytic activity in Eciton burchelli [54]. An interesting finding was revealed by a recombinant serine protease from Scleroderma guani venom with low trypsin-like catalytic activity; however, in biological tests in Tenebrio molitor larvae, this enzyme was able to inactivate the polyphenoloxidase enzyme that plays a key role in the immune cascade response of insects [57]. Furthermore, Hoffman et al. demonstrated that Hymenoptera proteases are also important allergic mediators with a high capacity to bind immunoglobulins IgE [58,59].

Initially, the ability to degrade a protein substrate was evaluated in a collagen copolymerized zymogram. Then, a quantitative analysis under the substrate azocasein demonstrated a potent proteolytic activity of the E. opaciventre venom. Our data reveal that the chelating activity of the phenanthroline, EGTA, and EDTA inhibitors is critical for part of the enzyme's components in the venom. The presence of proteases from Odontomachus bauri crude venom exerted an optimal activity at $\mathrm{pH} 8.0$ at $37^{\circ} \mathrm{C}$ on azocasein substrate, while in the presence of inhibitors the proteolytic activity was significantly reduced: aprotinin $(45 \%)$, aprotinin (25\%) and EDTA (9\%) [45]. In contrast to our data, the Odontomachus bauri venom did not show any influence of divalent cations tested on proteolytic activity.

Another fraction of significantly inhibited proteases occurred when the crude venom was previously treated with PMSF and aprotinin. PMSF and aprotinin are general inhibitors of serine proteases that react with serine residues to inhibit the catalytic site of enzymes such as trypsin, chymotrypsin, and thrombin, indicating the presence of this class in E. opaciventre venom. Whitworth and coworkers isolated and characterized the presence of four serine proteases from Solenopsis invicta larvae that were shown to be inhibited by diisopropyl fluorophosphate, an inhibitor of serine proteases [60]. Following this context, we can see that the results are highlighted by the increasement on enzymatic activity when the venom was previously incubated with $\mathrm{Ca}^{2+}$ and $\mathrm{Zn}^{2+}$ ions. It suggests that these cations are the main cofactors of the proteases present in the venom. Taken together, these results point to the presence of metalloproteases in the venom of Ectatomma opaciventre, which is already known for their presence in different animal venom and for cofactor $\mathrm{Zn}^{2+}$ [22].

The proteolytic activity in the presence of $\mathrm{Hg}^{2+}$ and $\mathrm{Ba}^{2+}$ was slightly inhibited, and the interference of metal ions in the proteolytic activity is widely described for venom metalloproteases, since the binding of these ions can lead to a conformational change and loss of activity. Interestingly, Scmidt et al., in 1986, carried out an enzymatic comparison between Hymenoptera venoms. In these findings, Ectatomma tuberculatum had low proteolytic activity of only 3 trypsin $\mathrm{U} / \mathrm{mg}$, according to a protocol established at the time, and Ectatomma quadridens venom did not show protease activity [54]. In the present work, we describe 
the Ectatomma opaciventre venom containing a high enzymatic activity as comparable to a purified metalloprotease from Bothrops pauloensis [22], revealing how potent the proteolytic fraction of this species is. Another class of enzymes was revealed in the venom when it was previously inhibited with Pepstatin A. Pepstatin A is a peptide inhibitor isolated from actinomycetes with specific action on the catalytic dyad of aspartate residues present in aspartic proteases [61].

\subsubsection{Phospholipases $A_{2}$}

Phospholipase $\mathrm{A}_{2}\left(\mathrm{PLA}_{2}\right)$ represents a family of enzymes that hydrolyze the sn-2 ester bond of phospholipids [62]. They are largely distributed enzymes in Hymenoptera and found in ant venoms; however, the Tetramorium caespitium venom does not have reported phospholipase activity [63], indicating that this is not a widely distributed enzyme in ant venoms. These enzymes play an important role in disrupting the lipid bilayer of cells leading to cell lysis, pore formation, and inflammation. In Hymenoptera venoms, these proteins are considered neurotoxic, cytotoxic, and potent allergens [64-67]. This is unlike snake phospholipases, as Hymenoptera phospholipases are not lethal to their prey, but they could exert a synergistic effect with toxic proteins leading to prey lethality [52,54]. We can find in the literature two isoforms of phospholipases isolated from Vespa affins wasp venom, Ves-A 1.01 and Ves-A 1.02. These enzymes exhibited high catalytic activity and thermal stability when heated. In addition, these enzymes showed paralytic activity in crickets, with $12.5 \mu \mathrm{g} / \mathrm{g}$ needed to immobilize $50 \%$ of the insects under study [68]. Furthermore, Sol 11 is a phospholipase with allergenic properties from the venom of Solenopsis invicta and showing high cross-reactivity with IgE from patients sensitized with the bite of other venomous Hymenoptera [69].

Ectatomma opaciventre venom showed indirect phospholipase activity in agar containing egg yolk and erythrocytes. The analysis of the phospholipase $\mathrm{A}_{2}$ repertoire of nine ant species demonstrated a range of activity among ant venoms in promoting agar diffusion halos, generally as low performance, except for the Pogonomyrmex baldius species, which showed equivalent phospholipase activity to Vespula squamosa and Vespula pensylvanica venom [54]. In this work, the E. tuberculatum and E. quadridens venoms weakly dissipated a phospholipase activity [54] in counterpoint with our findings, in which the E. opaciventre venom showed high catalytic activity, presenting $60 \%$ of the activity of an acidic PLA 2 isolated from Bothrops pauloensis [23], which demonstrated the presence of these enzymes in E. opaciventre crude venom.

\subsubsection{L-Amino Acid Oxidases (LAAOs)}

LAAOs are flavoenzymes that can catalyze the oxidative deamination of L-amino acid to its $\alpha$-ketoacid and release the production of hydrogen peroxide and ammonia. LAAOs are found in different types of organisms such as bacteria, fungi, and snake venoms [70,71]. E. opaciventre venom has a clear staining and strong activity of this enzyme when compared to Bp-LAAO, an isolated oxidase L-amino acid of Bothrops pauloensis [24]. According to this data, we can suggest that our work is the first report on the L-amino acid enzyme class found in hymenoptera venoms. In addition, the role of LAAOs in animal venoms is not fully understood; however, studies show that these enzymes have important biological activities, such as apoptotic, cytotoxic, bactericidal, and hemorrhagic [70,72-74]. These biotechnological and pharmaceutical applications of L-amino acid can be also explored by future E. opaciventre venom studies, opening a new and unexplored research aspect of toxinology.

\subsection{Analysis of Hemostatic Effects by E. opaciventre Venom}

Our data demonstrate that the venom is rich in enzymes, known as strong agents, capable of acting on the hemostatic system of prey. The venom of E. opaciventre showed a thrombolytic effect on fibrin red clot, however, it was not able to induce the coagulation and hydrolysis of fibrinogen chains. Collagen-induced platelet aggregation was also strongly 
inhibited by the venom and reinforced when there was a previous incubation of platelets with E. opaciventre venom, showing a partial inhibition of ADP and epinephrine. Our data suggest that E. opaciventre venom could mainly act on collagen receptors, such as $\alpha v \beta 3$ integrin. However, more investigation is necessary to completely explain the action mechanism on platelets. In this context, some similar findings on animal toxins have already shown the venom action by this receptor, which supports our data [75,76].

Our results also suggest the presence of fibrin-specific thrombolytic agents or activators and inhibitors of platelet aggregation of fibrinolysis [77], which can interfere with the blood coagulation cascade. The fibrinogenolytic activity from ant venom remains unclear; Odontomachus bauri venom, for example, not only showed fibrinogenolytic activity on fibrinogen $\alpha$ and $\beta$ chains, but also exerted strong coagulant activity in bovine plasma in about $15 \mathrm{~s}$, when compared to the positive control demonstrating the high variability of effects and plasticity of ant venoms [45]. Usually, predatory ant diets are composed of insect larvae, arthropods, and annelids, which means less evolutionary function for hunting. The effects and meanings of the role of these toxins for prey catching remains unknown; the presence of enzymes with a hemostasis effect in the venom may have evolved into a defense mechanism against predators, as birds and small mammals have ants as the base of their food chain.

\subsection{Biotechnological Potential of E. opaciventre Venom}

The results demonstrate a good scenario for bioprospecting, which reveals this venom as an untapped rich source of protein compounds. Despite considerable advances in pharmacological and non-pharmacological treatments, cancer remains one of the most common causes of death around the world. When we consider different types of cancer, lung cancer grows at an incidence of $2 \%$ per year, registering around 1.7 million new cases $[78,79]$. Despite advances in new therapies, lung cancer remains a major challenge in the development of new antitumor agents, since resistance to chemotherapeutics develops during treatment, showing a low toxicity by the treatment and the selectivity of compounds by tumor cells [79].

In agreement with the biological characterization of E. opaciventre venom, we investigated the cytotoxic effects in lung tumor and non-tumor cell lines. The E. opaciventre venom showed a higher cytotoxic effect against the A549 cells (lung tumor cells). Otherwise, to BEAS-2B, a non-tumorigenic bronchus cell, the venom only showed cytotoxicity at the highest concentration $(100 \mu \mathrm{g} / \mathrm{mL})$, suggesting a selectivity ability of some venom components by tumor cell types. Similar effects were reported with the action of Pachycondyla sennearensis venom in MCF-7, a breast cancer line. In this report, P. sennearensis induced cell death by apoptosis, inhibiting cell proliferation and F-actin polymerization, through an IGF-1-independent pathway [80].

Another important bioprospecting potential is treating Leishmaniosis. Leishmaniosis is a neglected tropical disease, which has a therapeutic approach with low efficacy and high toxicity for patients. Therefore, new studies which are looking for potential molecules for the treatment of these diseases have gained prominence [81,82]. Dinoponera quadriceps venom has demonstrated antiparasitic effects by inducing cell death in the promastigotes of L. amazonensis [13]. In this context, our work addressed the cytotoxic profile of E. opaciventre venom in three species of Lesihmania. We evaluated the response in Leishmania amazonensis and Leishmania brasiliensis, responsible for the integumentary manifestation of the disease, and in Lesihmania infantum, which causes the visceral form of leishmaniasis. The venom of E. opaciventre showed the capacity to interfere with the viability of the promastigote forms of these parasites, showing higher cytotoxic action against L. infatum and L. amazonensis. Moreover, the promastigote form of Leishmania brasiliensis has been shown to be more resistant in vitro to cytotoxic components present in the venom. The $\mathrm{IC}_{50}$ value of E. opaciventre venom was lower than those already shown by Dinoponera quadriceps venom, even for Leishmania braziliensis, which was more resistant to E. opaciventre venom. In addition, our 
data were able to show a high selectivity of the venom for parasites, as well as demonstrate its low toxicity in macrophages isolated from mice.

The data generated confirm the E. opaciventre venom as a promising source for biomolecules with biotechnological applications in processes involving the hemostatic system, as well as helping to discover new therapies for diseases such as cancer and parasites.

\section{Conclusions}

This study reports the first investigation on the biochemical, enzymatic, and functional characteristics of the venom from the solitary foraging predatory ant species Ectatomma opaciventre. We also investigated its bioprospecting properties. This venom presented a great diversity of proteins and peptides, with these components showing high enzymatic activity. First, we reported the profile and preference of Hymenoptera venoms for hydrolysis of hyaluronidases, which indicate an unpublished presence of LAAOs in ant venom.

The venom action on hemostatic system demonstrates that it was able to act on primary hemostasis inhibiting platelet aggregation, mainly agonized by collagen. The proteases present in the venom demonstrated thrombolytic activity in red blood clots. In addition, the bioactive compounds present in the venom also demonstrated a high cytotoxic effect on tumor cell lines, in contrast to the low cytotoxicity in a non-tumorigenic cell line. A broad antiparasitic spectrum was also observed in the activity on parasites unicellular and multicellular. Thus, the Ectatomma opaciventre ant venom presents biomolecules with high potential for the development of new research tools or therapeutical drugs of high interest in different disease models. In summary, our work opened a new source to investigate the Ectatomma opaciventre venom components and their pharmacological application to design new therapy approaches for many diseases.

\section{Materials and Methods}

\subsection{Venom Preparation}

The ants were collected at Panga Ecological Station, a private protected area belonging to the Federal University of Uberlândia, located $30 \mathrm{~km}$ south of Uberlândia in the state of Minas Gerais, Brazil $\left(19^{\circ} 10^{\prime} \mathrm{S}\right.$ and $\left.48^{\circ} 24^{\prime} \mathrm{W}\right)$, and immediately transferred to the laboratory. The venom gland was pinched out with entomological forceps and placed in a microtube with $7.5 \%$ acetonitrile and $0.05 \%$ trifluoracetic acid/distilled water. The glands were disrupted by cold ultrasonic bath and centrifuged at $320 \times g$ for $2 \mathrm{~min}$. Membrane debris and empty venom sacs were discarded. Total protein was measured by the Bradford assay [38]. The samples were lyophilized and kept at $-80^{\circ} \mathrm{C}$.

\subsection{Biological Samples}

The crude venom of Bothrops pauloensis and Crotalus durrissus collilineatus was obtained from specimens kept in the Animal Toxin Extraction Center Ltd.-(CETA serpentarium), Morungaba, Sao Paulo, Brazil. This serpentarium has proof of registration of IBAMA and renewable natural resources ( $\mathrm{n}^{\circ}$ 2087163). Toxins isolated from the crude venom of Bothrops pauloensis were generously assigned to the work by Prof. Dr. Veridiana de Melo Rodrigues from the Federal University of Uberlândia. The venom of Tityus serrulatus was kindly given by Prof. Dr. Eliane Candiani Arantes' research group. The specimens were obtained from the region of Ribeirão Preto and were maintained in the serpentarium of the Faculdade de Medicina de Ribeirão Preto (FMRP-USP, University of São Paulo at School of Medicine of Ribeirão Preto), Brazil, in accordance with the guidelines of Ibama, Brazilian Institute of Environment. Bovine blood and fractions were obtained at the experimental farm of the Federal University of Uberlândia. All the experiments were conducted according to the standards recommended by the CEUA/UFU. The bone marrow-derived macrophages (BMDM) were collected from female BALB/c mice, supplied by the animal facility of the Federal University of Uberlândia (CBEA/UFU) under the registration protocol 096/15 (CEUA/UFU, approved in November 2015). 


\subsection{Polyacrylamide Gel Electrophoresis (SDS-PAGE)}

Gels were performed, as described by Laemmli et al. 1970 [83], using a continuous buffering system. The following solutions were used in $12.5 \%$ and $21 \%$ polyacrylamide gel electrophoresis $(w / v)$ with denaturing agents sodium dodecyl sulfate (SDS). Proteins were stained with a solution of Coomassie blue R-250 and peptides were stained with silver (Sigma-Aldrich, Saint Louis, MO, USA). Molecular size markers (MrS) (Thermo Scientific \#26610, Waltham, MA, USA) and (Ultra-low Range Molecular M354, Sigma) were used in the appropriate electrophoretic run.

\subsection{Enzymatic Activities}

\subsubsection{Fibrinogenolytic Activity}

Fibrinogenolytic activity was evaluated, as described by Rodrigues et al. (2000) [84], with some modifications. Briefly, samples of $50 \mu \mathrm{L}$ of bovine fibrinogen (Sigma-Aldrich), $1.5 \mathrm{mg} / \mathrm{mL}$, in phosphate buffered saline (PBS), $\mathrm{pH} 7.8$, were incubated with different crude venom concentrations $(0.5 \mu \mathrm{g} ; 1 \mu \mathrm{g} ; 2.5 \mu \mathrm{g} ; 5 \mu \mathrm{g} ; 10 \mu \mathrm{g})$ for $2 \mathrm{~h}$ at $37^{\circ} \mathrm{C}$. The reaction was stopped with $25 \mu \mathrm{L}$ of $0.06 \mathrm{M}$ Tris- $\mathrm{HCl}, \mathrm{pH} 6.8$, containing $10 \%(v / v)$ glycerol, $10 \%(v / v)$ $\beta$-mercaptoethanol, $2 \%(w / v)$ SDS, and $0.05 \%(w / v)$ bromophenol blue. The samples were then heated at $100{ }^{\circ} \mathrm{C}$ for $5 \mathrm{~min}$ and analyzed by $12.5 \%$ SDS-PAGE.

\subsubsection{Azocaseinolytic Activity}

Enzymatic characterization of crude venom was initially achieved using azocasein as a substrate according to Gomes et al. (2011) [22], with modifications. Samples containing $800 \mu \mathrm{L}$ of azocasein (Sigma-Aldrich) $(1 \mathrm{mg} / \mathrm{mL})$ in PBS were incubated for $30 \mathrm{~min}$ at $37^{\circ} \mathrm{C}$ with $5 \mu \mathrm{g}$ of crude venom. Next, $100 \mu \mathrm{L}$ of $20 \%$ trichloroacetic acid (m/v) was added to each sample. They were incubated at room temperature for $30 \mathrm{~min}$, and then centrifuged at $1856 \times \mathrm{g}$ for $20 \mathrm{~min}$. The absorbance of the supernatant was determined at $405 \mathrm{~nm}$ by a BioTek EL800 reader. One unit (U) of azocaseinolytic activity was defined as an increase of 0.01 absorbance units at $405 \mathrm{~nm}$ under standard assay conditions.

The effect of protease inhibitors, $10 \mathrm{~mm}$ 1,10-phenanthroline, phenylmethylsulfonyl fluoride (PMSF), ethylenediamine tetraacetic acid (EDTA), and divalent cations, $10 \mathrm{mM}$, $\left(\mathrm{Ca}^{2+}, \mathrm{Mg}^{2+}, \mathrm{Zn}^{2+}, \mathrm{Cu}^{2+}, \mathrm{Hg}^{2+}\right.$ and $\left.\mathrm{Ba}^{2+}\right)$ on azocaseinolytic activity was evaluated by incubating $5 \mu \mathrm{g}$ of crude venom for $1 \mathrm{~h}$ at $37^{\circ} \mathrm{C}$. The enzymatic assay was performed as described above. The positive control was used $5 \mu \mathrm{g}$ of Bothropoidin, a metalloprotease from Bothrops pauloensis venom [22].

\subsubsection{Zymography}

Zimography was carried out according to Cevallos et al. (1992) [46], based on the electrophoresis system described by Laemmli (1970) [28], with adaptations. In this method, hyaluronic acid $(0.4 \mathrm{mg} / \mathrm{mL})$ and gelatin $(1.0 \mathrm{mg} / \mathrm{mL})$ were incorporated into the gel matrix during polymerization process. The analyzed samples were not reduced by $\beta$ mercaptoethanol and no denaturation occurred by heating to $100^{\circ} \mathrm{C}$. After the electrophoresis, the gel was washed twice for $30 \mathrm{~min}$ at room temperature in 2.5\% Triton X-100 (SigmaAldrich) to remove the SDS. The gels were stained with R-250 Coomassie blue. Gelatin and hyaluronan enzyme activity were detected as colorless bands in the otherwise blue gel.

\subsubsection{Hyaluronidase Activity}

The hyaluronidase activity was determined quantitatively by turbidimetry through a modified version of the Di Ferrante method (1956) [85] and adapted to a 96-well flat-bottom microplate. The acetate buffer ( $200 \mathrm{~mm}$ sodium acetate, $150 \mathrm{~mm} \mathrm{NaCl} \mathrm{pH} \mathrm{6.0),} 10 \mu \mathrm{g}$ hyaluronan, and different substrates, such as chondroitin-4 (Chondroitin sulphate $\mathrm{C}$ ) dermatan and chondroitin-6-sulphate (Sigma, Marlborough, MA, USA) $(0.5 \mathrm{mg} / \mathrm{mL}$ in water), were adjusted within the final reaction volume to $200 \mu \mathrm{L}$, with different concentrations of crude venom. The mixture was incubated for $30 \mathrm{~min}$ at $37^{\circ} \mathrm{C}$ and the reaction was quenched with the addition of $100 \mu \mathrm{L}$ of $5 \%$ cetyltrimethylammonium bromide (CTAB) 
$(w / v)$ and $4 \% \mathrm{NaOH}(w / v)$. The microplate was read within $10 \mathrm{~min}$ in a microplate reader (Multiskan GO Thermo Scientific, Waltham, MA, USA), using a wavelength of $400 \mathrm{~nm}$. The turbidimetric reduction unit (UTR) will be expressed as the amount of enzyme required to hydrolyze $50 \%$ of the hyaluronic acid.

\subsubsection{Phospholipase Activity}

The phospholipase assay was performed according to De Haas and Postema (1968) [86]. Phospholipase activity was measured using egg yolk as the substrate in the presence of $0.03 \mathrm{~m}$ sodium deoxycholate and $0.6 \mathrm{~m} \mathrm{CaCl}_{2}$. The mixture was incubated with $5 \mu \mathrm{g}$ of crude venom. Results were expressed as $\mathrm{mEqNaOH} / \mathrm{mg} / \mathrm{min}$. The positive control was 5 $\mu \mathrm{g}$ of Bp-TxI-PLA ${ }_{2}$, from Bothrops pauloensis.

For the indirect Phospholipase activity, we used the method described by Schröder et al. (1971) [87]. Briefly, PBS with 1.0\% agarose was added under heating, until a clear colloid (final volume $10 \mathrm{~mL}$ ) was formed. After cooling, the agarose solution $\left( \pm 40{ }^{\circ} \mathrm{C}\right)$ washed bovine erythrocytes, $0.01 \mathrm{~m} \mathrm{CaCl}_{2}$, egg yolk (in the ratio of 1:3 PBS), and 0.005\% sodium azide $(w / v)$; the resulting solution was poured into a petri dish (the plate was maintained at room temperature for $30 \mathrm{~min}$ ). The samples were applied in holes in the gel at the desired concentrations $(10 \mu \mathrm{g}$ and $20 \mu \mathrm{g})$, at the final volume of $30 \mu \mathrm{L}$, followed by incubation at $37^{\circ} \mathrm{C}$ for $24 \mathrm{~h}$ and subsequent measurement of the halos.

\subsubsection{L-Amino Acid Oxidase Assay}

LAAO activity was measured by an adaptation of the method previously described by Ponnudurai et al. (1994) [88]. In this assay, the oxidative deamination of different L-amino acids produced hydrogen peroxide, which was reduced in the presence of horseradish peroxidase (HRP) by o-phenylenediamine to produce a colored oxidized product, which was spectrophotometrically monitored at $490 \mathrm{~nm}$. Briefly, $5 \mu \mathrm{g}$ of crude venom was incubated at $37^{\circ} \mathrm{C}$ for $1 \mathrm{~h}$ with $195 \mu \mathrm{L}$ of a solution containing $80 \mu \mathrm{g}$ of $o$-phenylenediamine, $8 \mathrm{mg}$ of L-amino acids, and $10 \mu \mathrm{L} \mathrm{HRP}(1 \mathrm{mg} / \mathrm{mL})$ in $10 \mathrm{~mm}$ Tris-HCl buffer at pH 7.2. The reaction was stopped by the addition of $100 \mu \mathrm{L}$ of $10 \%(w / v)$ citric acid. One unit $(1$ $\mathrm{U})$ of enzyme activity was defined as the amount of enzyme able to produce $1 \mathrm{mmol}$ of hydrogen peroxide/min, under the described conditions.

\subsection{Biological Activities}

\subsubsection{Coagulant Activity}

Coagulant activity on bovine plasma was performed as described by Assakura et al. (1992) [89], with modifications. Different concentrations of the crude venom were prepared in a final volume of $50 \mu \mathrm{L}$ in $0.06 \mathrm{M}$ Tris- $\mathrm{HCl}$ buffer, $\mathrm{pH}$ 7.2. Then, $0.2 \mathrm{M}$ calcium chloride was added to $150 \mu \mathrm{L}$ of bovine plasma and incubated at $37^{\circ} \mathrm{C}$. The samples were kept under constant and gentle stirring. The time required to start the formation of the fibrin network was recorded by a photometric system in the coagulometer Quick Timer II (Draker-BR) and compared with the positive and negative control groups. Clotting time duration of more than $240 \mathrm{~s}$ was considered indicative of a non-coagulant sample. As control of the reaction, we used $50 \mu \mathrm{g}$ of Crotalus durrissus collilineatus venom.

\subsubsection{Thrombolytic Activity}

Thrombolytic activity was assessed by dissolving thrombi on a 24-well plate. Briefly, bovine blood collected in the absence of anticoagulants. Briefly, bovine blood was collected and $1 \mathrm{~mL}$ of blood per well was placed in the plate and incubated at $37^{\circ} \mathrm{C}$ for spontaneous clotting. The clots obtained were treated with different amounts of venom $(50 \mu \mathrm{g}$ and $100 \mu \mathrm{g}$ ), adjusted to $500 \mu \mathrm{L}$ of final solution with PBS for $48 \mathrm{~h}$ at $37^{\circ} \mathrm{C}$. For positive control $50 \mu \mathrm{g}$ of Bothrops pauloensis venom was used and for negative control PBS was used. After treatment, the clots were measured and weighed to evaluate the activity. 


\subsubsection{Platelet Aggregation Assay}

Platelet aggregation assays were performed on bovine platelet-rich plasma (PRP) and measured using an automated 4-channel Aggregometer (AggRAM version 1.1, Helena Laboratories). Blood collected from bovines was placed in sodium citrate $(3.2 \%, w / v)$ and centrifuged at $100 \times g$ for $12 \mathrm{~min}$ at room temperature to obtain PRP. Platelet-poor plasma (PPP) was obtained from the residue by centrifugation of citrated blood at $1000 \times g$ for $15 \mathrm{~min}$, used for instrument calibration. Assays were carried out using $200 \mu \mathrm{L}$ of PRP maintained at $37{ }^{\circ} \mathrm{C}$ under continuous stirring in siliconized glass cuvettes. Aggregation was triggered with collagen $(10 \mu \mathrm{g} / \mathrm{mL})$, adenosine diphosphate (ADP) $(20 \mu \mathrm{M})$, or epinephrine $(300 \mu \mathrm{M})$. Agonists were added concomitantly with the E. opaciventre venom in the platelet solution at the time of testing, or the platelets were pre-treated for $20 \mathrm{~min}$ with the crude venom. One hundred percent (100\%) aggregation was expressed as the percentage absorbance relative to PPP aggregation. Control experiments were performed using only platelet agonists.

\subsubsection{Cell Viability Assay \\ Cell Culture}

The human cell line BEAS-2B (CRL-9609), non-tumorigenic bronchus cell, and A549 (CRM-CCL-185), an adenocarcinoma human alveolar basal epithelial cell, were used. Cells were obtained from the American Type Culture Collection (ATCC; Virginia, USA). The BEAS-2B and A549 cells were grown in RPMI-1640 medium (Sigma), supplemented with $10 \%$ fetal bovine serum (FBS) (Cultilab) and containing $100 \mathrm{U} / \mathrm{mL}$ penicillin and $100 \mu \mathrm{g} / \mathrm{mL}$ streptomycin (Sigma). Cell cultures were incubated at $37{ }^{\circ} \mathrm{C}$ with $5 \% \mathrm{CO}_{2}$.

\section{MTT Assay}

For the viability assays, the A549 and BEAS-2B cells were treated with crude venom following the methodology of Mosmann (1983) [90] and assessed by an MTT assay [3-(4,5dimethylthiazol-2-yl)-2,5-diphenyltetrazolium bromide], with few modifications. Briefly, cells were seeded on 96-well plates at the density of $2 \times 10^{4}$ cells/well followed by incubation for $24 \mathrm{~h}$ at $37^{\circ} \mathrm{C}$ in a humidified incubator containing $5 \% \mathrm{CO}_{2}$. After this period, cells were treated with different concentrations (two-fold serial dilution from $100 \mu \mathrm{g} / \mathrm{mL}$ to $0.048 \mu \mathrm{g} / \mathrm{mL}$ ) of E. opaciventre crude venom for $24 \mathrm{~h}$. After the treatment, $20 \mu \mathrm{L}$ MTT per well (Sigma M2128, Marlborough, MA, USA) $(5 \mathrm{mg} / \mathrm{mL})$ was added and incubated for $3 \mathrm{~h}$, and the formazan crystals were dissolved in $100 \mu \mathrm{L}$ PBS with $10 \%$ SDS and $0.01 \mathrm{~N} \mathrm{HCl}$ for $18 \mathrm{~h}$ until the complete dissolution of the crystals. Optical density was determined at $570 \mathrm{~nm}$ in a plate reader (Multiskan GO Thermo Scientific, Waltham, MA, USA). Viability was expressed as a percentage compared to the untreated control.

$$
\text { Viability }(\%)=\frac{\mathrm{Abs}_{570 \text { sample }}-\mathrm{Abs}_{570 \text { control }}}{\mathrm{Abs}_{570} \text { control }} \times 100
$$

\subsubsection{Antiparasitic Activity}

Leishmania Promastigote Culture

Leishmania (Leishmania) amazonensis (IFLA/BR/67/PH8 strain), Leishmania (Viannia.) braziliensis (MHOM/BR/75/M2904 strain), and Leishmania (Leishmania) infantum (MCER/ BR/79/M6445 strain) promastigotes were cultured in Liver Infusion Tryptose LIT medium, $\mathrm{pH}$ 7.4, supplemented with $10 \% \mathrm{FBS}$, penicillin $\left(100 \mathrm{UI} \mathrm{mL}^{-1}\right)$, and streptomycin $\left(100 \mu \mathrm{g} \mathrm{mL}^{-1}\right)$, in $2 \%$ glucose $(w / v)$-complete LIT—at $23 \pm 0.5^{\circ} \mathrm{C}$. Promastigotes used in all experiments were isolated from the stationary growth phase. Promastigotes $\left(5 \times 10^{5}\right.$ promastigote/well $)$ were placed on 96-well culture plates and incubated at $23^{\circ} \mathrm{C}$ with different concentrations of crude venom (two-fold serial dilution from $100 \mu \mathrm{g} / \mathrm{mL}$ to $0.048 \mu \mathrm{g} / \mathrm{mL}$ ) for $72 \mathrm{~h}$. The cell viabilities were evaluated by the MTT assay according to Mosmann (1983) [90], with some modifications; and the $50 \%$ inhibitory concentration $\left(\mathrm{IC}_{50}\right)$ of venom on cell viability was then determined by GraphPad Prism 5.0 (GraphPad Software Inc., San Diego, CA, USA). 
Evaluation of Susceptibility of Mouse Bone Marrow-Derived Macrophages (BMDM) Treated with E. opaciventre Venom

BMDM were obtained by differentiating bone marrow cells from female BALB/C mice (aged 7-9 weeks), as previously described [26] and approved by ethical statement 096/15 (CEUA/UFU). Briefly, in this method, cells obtained from the bone marrow are processed to remove red blood cells. After this step, cells are resuspended in RPMI medium containing 20\% L929 supernatant and cultured for 7 to 8 days for cell differentiation. Then, macrophages $\left(2 \times 10^{5}\right.$ cells/well) were plated in 96-well culture plates containing RPMI 1640 medium supplemented with $20 \% \mathrm{FBS}, 1 \%$ penicillin $\left(10,000 \mathrm{UI} \mathrm{mL}^{-1}\right)$, and streptomycin $\left(10 \mathrm{mg} \mathrm{mL}^{-1}\right)$, in $1.3 \%$ glutamine $(w / v)$-complete RPMI medium-in an incubator containing $5 \% \mathrm{CO}_{2}$ at $37{ }^{\circ} \mathrm{C}$ for $18 \mathrm{~h}$. After, BMDM were incubated with a complete RPMI medium in the absence (control) or presence of different concentrations (two-fold serial dilution from $100 \mu \mathrm{g} / \mathrm{mL}$ to $0.78 \mu \mathrm{g} / \mathrm{mL}$ ) of crude venom for $24 \mathrm{~h}$. The cell viabilities were assessed by the MTT assay according to Mosmann, as described before [90].

\subsection{Statistical Analysis}

All assays were performed in triplicate. The statistical analysis of variance (ANOVA) and Student's t-test, with a significance level of $5 \%(p<0.05)$ represented by an asterisk signal, were performed using the software GraphPad Prism, version 9.0 (GraphPad Program Inc., San Diego, CA, USA).

Author Contributions: Experimental design and manuscript writing, L.I.V.C., F.G.A., S.N.C.G. and R.S.R.; performance of experiments, L.I.V.C., F.V.P.d.V.A., F.G.A., M.S.C., S.N.C.G., J.P.R., L.P. and J.C.S.; performance of statistical analysis, L.I.V.C., F.G.A., M.A.P.Z. and F.V.P.d.V.A.; revision of the manuscript, L.R.G., K.A.G.Y., E.C.A., V.d.M.R. and R.S.R. All authors have read and agreed to the published version of the manuscript.

Funding: This study received financial support from Fundação de Amparo à Pesquisa do Estado de Minas Gerais (FAPEMIG, Foundation for Research Support of the State of Minas Gerais, n. APQ-01307-17, APQ01777-14, APQ-02531-15, CBB-APQ01637-15, CBB-APQ-0140117), Fundação de Amparo à Pesquisa do Estado de São Paulo (FAPESP, São Paulo Research Foundation, scholarship to FGA, n. 2011/12317-3), Conselho Nacional de Desenvolvimento Científico e Tecnológico (CNPq, scholarship to F.G.A n. 150037/2018-0 and to J.C.S n. 312752/2018-0) and Coordenação de Aperfeiçoamento de Pessoal de Nível Superior (CAPES) and National Intitute of Science and Techonology in Theranostics and Nanobiotechnology INCT-TeraNano-CNPq/CAPES/FAPEMIG, Grant numbers CNPq-465669/2014-0. The au-thors are grateful to the laboratory technician Marina Lima for the technical support throughout this work.

Institutional Review Board Statement: Bovine blood and fractions were obtained at the experimental farm of the Federal University of Uberlândia. All the experiments were conducted according to the standards recommended by the CEUA/UFU. The bone marrow-derived macrophages (BMDM) were collected from female BALB/c mice supplied by the animal facility of the Federal University of Uberlândia (CBEA/UFU), under the registration protocol 096/15 (CEUA/UFU, approved in November 2015).

Informed Consent Statement: Not applicable.

Data Availability Statement: Data available in a publicly accessible repository that does not issue DOIs Publicly available datasets were analyzed in this study. This data can be found here: https: / / repositorio.ufu.br/?locale=pt_BR (accessed on23 December 2021).

Acknowledgments: The authors are grateful to the laboratory technician Marina Lima for the technical support throughout this work. The authors would like to pay homage to Luiz Ricardo Goulart, who died from complications resulting from COVID. Luiz Ricardo was a great Brazilian scientist. He has been involved in the main causes of science and the improvement of Brazilian society, working in different areas, including the development of new diagnostic platforms for the detection of SARS-CoV. He was an extremely generous scientist with a passion for research who left a great legacy of knowledge to the scientific community. Thank you very much for your generous contribution to Brazilian science. 
Conflicts of Interest: The authors declare no conflict of interest.

\section{References}

1. Brady, S.G.; Schultz, T.R.; Fisher, B.; Ward, P.S. Evaluating alternative hypotheses for the early evolution and diversification of ants. Proc. Natl. Acad. Sci. USA 2006, 103, 18172-18177. [CrossRef] [PubMed]

2. Keller, R. A Phylogenetic Analysis of Ant Morphology (Hymenoptera: Formicidae) with Special Reference to the Poneromorph Subfamilies. Bull. Am. Mus. Nat. Hist. 2011, 355, 1-90. [CrossRef]

3. Ward, P.S. The phylogeny and evolution of ants. Annu. Rev. Ecol. Evol. Syst. 2014, 45, 23-43. [CrossRef]

4. Aili, S.R.; Touchard, A.; Escoubas, P.; Padula, M.P.; Orivel, J.; Dejean, A.; Nicholson, G.M. Diversity of peptide toxins from stinging ant venoms. Toxicon 2014, 92, 166-178. [CrossRef]

5. Kolay, S.; Boulay, R.; D'Ettorre, P. Regulation of ant foraging: A review of the role of information use and personality. Front. Psychol. 2020, 11, 734. [CrossRef]

6. Dos Santos-Pinto, J.R.A.; Perez-Riverol, A.; Lasa, A.M.; Palma, M.S. Diversity of peptidic and proteinaceous toxins from social Hymenoptera venoms. Toxicon 2018, 148, 172-196. [CrossRef]

7. Touchard, A.; Aili, S.R.; Fox, E.G.P.; Escoubas, P.; Orivel, J.; Nicholson, G.M.; Dejean, A. The biochemical toxin arsenal from ant venoms. Toxins 2016, 8, 30. [CrossRef]

8. Laxme, R.S.; Suranse, V.; Sunagar, K. Arthropod venoms: Biochemistry, ecology and evolution. Toxicon 2019, 158, 84-103. [CrossRef]

9. Mesquita, A.M.; Carneiro-Leão, L.; Amaral, L.; Coimbra, A. Hymenoptera venom allergy Re-Sting reactions. Eur. Ann. Allergy Clin. Immunol. 2021, 53, 94. [CrossRef] [PubMed]

10. Adelmeyer, J.; Pickert, J.; Pfützner, W.; Möbs, C. Long-term impact of hymenoptera venom immunotherapy on clinical course, immune parameters, and psychosocial aspects. Allergol. Sel. 2021, 5, 57-66. [CrossRef] [PubMed]

11. Bordon, K.D.C.F.; Cologna, C.T.; Fornari-Baldo, E.C.; Pinheiro-Júnior, E.L.; Cerni, F.A.; Amorim, F.G.; Anjolette, F.A.P.; Cordeiro, F.A.; Wiezel, G.A.; Cardoso, I.A.; et al. From animal poisons and venoms to medicines: Achievements, challenges and perspectives in drug discovery. Front. Pharmacol. 2020, 11, 1132. [CrossRef]

12. Fox, E.G.P.; Solis, D.R.; dos Santos, L.D.; Pinto, J.R.A.D.S.; Menegasso, A.R.D.S.; Silva, R.C.M.C.; Palma, M.S.; Bueno, O.C.; de Alcântara Machado, E. A simple, rapid method for the extraction of whole fire ant venom (Insecta: Formicidae: Solenopsis). Toxicon 2013, 65, 5-8. [CrossRef]

13. Lima, D.B.; Sousa, P.L.; Torres, A.F.; da França Rodrigues, K.A.; Mello, C.P.; Tessarolo, L.D.; Quinet, Y.P.; de Oliveira, M.R.; Martins, A.M. Antiparasitic effect of Dinoponera quadriceps giant ant venom. Toxicon 2016, 120, 128-132. [CrossRef] [PubMed]

14. Lima, D.; Torres, A.; Mello, C.; Menezes, R.; Sampaio, T.; Canuto, J.; Da Silva, J.; Freire, V.; Quinet, Y.; Havt, A.; et al. Antimicrobial effect of Dinoponera quadriceps (Hymenoptera: Formicidae) venom against Staphylococcus aureus strains. J. Appl. Microbiol. 2014, 117, 390-396. [CrossRef] [PubMed]

15. Sousa, P.L.; Quinet, Y.; Ponte, E.L.; Vale, J.F.D.; Torres, A.F.C.; Pereira, M.G.; Assreuy, A.M.S. Venom's antinociceptive property in the primitive ant Dinoponera quadriceps. J. Ethnopharmacol. 2012, 144, 213-216. [CrossRef]

16. Touchard, A.; Aili, S.R.; Téné, N.; Barassé, V.; Klopp, C.; Dejean, A.; Kini, R.M.; Mrinalini, M.; Coquet, L.; Jouenne, T.; et al. Venom peptide repertoire of the European myrmicine ant Manica rubida: Identification of Insecticidal Toxins. J. Proteome Res. 2020, 19, 1800-1811. [CrossRef] [PubMed]

17. Ebaid, H.; Abdel-Salam, B.; Alhazza, I.; Al-Tamimi, J.; Hassan, I.; Rady, A.; Mashaly, A.; Mahmoud, A.; Sammour, R. Samsum ant venom modulates the immune response and redox status at the acute toxic dose in vivo. J. Venom. Anim. Toxins Incl. Trop. Dis. 2019, 25, e20190020. [CrossRef]

18. Pie, M.R. Foraging ecology and behaviour of the ponerine ant Ectatomma opaciventre Roger in a Brazilian savannah. J. Nat. Hist. 2004, 38, 717-729. [CrossRef]

19. Arseniev, A.; Pluzhnikov, K.; Nolde, D.; Sobol, A.; Sukhanov, S.; Grishin, E.; Torgov, M. Toxic principle of selva ant venom is a pore-forming protein transformer. FEBS Lett. 1994, 347, 112-116. [CrossRef]

20. Nolde, D.; Sobol, A.G.; Pluzhnikov, K.A.; Grishin, E.V.; Arseniev, A.S. Three-dimensional structure of ectatomin from Ectatomma tuberculatum ant venom. J. Biomol. NMR 1995, 5, 1-13. [CrossRef]

21. Pluzhnikov, K.A.; Kozlov, S.A.; Vassilevski, A.A.; Vorontsova, O.V.; Feofanov, A.V.; Grishin, E.V. Linear antimicrobial peptides from Ectatomma quadridens ant venom. Biochimie 2014, 107, 211-215. [CrossRef] [PubMed]

22. Gomes, M.S.R.; De Souza, D.L.N.; Guimaraes, D.O.; Lopes, D.S.; Mamede, C.C.N.; Gimenes, S.N.C.; Ache, D.C.; Rodrigues, R.S.; Yoneyama, K.A.G.; Borges, M.H.; et al. Biochemical and functional characterization of Bothropoidin: The first haemorrhagic metalloproteinase from Bothrops pauloensis snake venom. J. Biochem. 2014, 157, 137-149. [CrossRef] [PubMed]

23. Ferreira, F.B.; Gomes, M.S.R.; De Souza, D.L.N.; Gimenes, S.N.C.; Castanheira, L.E.; Borges, M.H.; Rodrigues, R.S.; Yoneyama, K.A.G.; Brandeburgo, M.I.H.; Rodrigues, V.M. Molecular cloning and pharmacological properties of an acidic PLA2 from Bothrops pauloensis snake venom. Toxins 2013, 5, 2403-2419. [CrossRef] [PubMed]

24. Rodrigues, R.S.; da Silva, J.; França, J.B.; Fonseca, F.P.; Otaviano, A.R.; Silva, F.H.; Hamaguchi, A.; Magro, A.J.; Braz, A.S.K.; Dos Santos, J.I. Structural and functional properties of Bp-LAAO, a new l-amino acid oxidase isolated from Bothrops pauloensis snake venom. Biochimie 2009, 91, 490-501. [CrossRef] 
25. Walker, A.A. The evolutionary dynamics of venom toxins made by insects and other animals. Biochem. Soc. Trans. 2020, 48, 1353-1365. [CrossRef]

26. Calvete, J.J. Venomics: Integrative venom proteomics and beyond. Biochem. J. 2017, 474, 611-634. [CrossRef] [PubMed]

27. Kaas, Q.; Craik, D.J. Bioinformatics-aided venomics. Toxins 2015, 7, 2159-2187. [CrossRef]

28. Torres, A.F.C.; Huang, C.; Chong, C.-M.; Leung, S.W.; Prieto, A.; Havt, A.; Quinet, Y.P.; Martins, A.M.C.; Lee, S.M.Y.; RádisBaptista, G. Transcriptome analysis in venom gland of the predatory giant ant Dinoponera quadriceps: Insights into the polypeptide toxin arsenal of hymenopterans. PLoS ONE 2014, 9, e87556. [CrossRef]

29. Touchard, A.; Téné, N.; Song, P.C.T.; Lefranc, B.; Leprince, J.; Treilhou, M.; Bonnafé, E. Deciphering the molecular diversity of an ant venom peptidome through a venomics approach. J. Proteome Res. 2018, 17, 3503-3516. [CrossRef]

30. Aili, S.R.; Touchard, A.; Hayward, R.; Robinson, S.D.; Pineda, S.S.; Lalagüe, H.; Vetter, I.; Undheim, E.A.B.; Kini, R.M.; Escoubas, P.; et al. An integrated proteomic and transcriptomic analysis reveals the venom complexity of the bullet ant Paraponera clavata. Toxins 2020, 12, 324. [CrossRef]

31. Aili, S.R.; Touchard, A.; Petitclerc, F.; Dejean, A.; Orivel, J.; Padula, M.P.; Escoubas, P.; Nicholson, G.M. Combined peptidomic and proteomic analysis of electrically stimulated and manually dissected venom from the South American bullet ant Paraponera clavata. J. Proteome Res. 2017, 16, 1339-1351. [CrossRef]

32. Wanandy, T.; Wilson, R.; Gell, D.; Rose, H.E.; Gueven, N.; Davies, N.W.; Brown, S.G.A.; Wiese, M.D. Towards complete identification of allergens in Jack Jumper (Myrmecia pilosula) ant venom and their clinical relevance: An immunoproteomic approach. Clin. Exp. Allergy 2018, 48, 1222-1234. [CrossRef] [PubMed]

33. Gatti, J.-L.; Belghazi, M.; Legeai, F.; Ravallec, M.; Frayssinet, M.; Robin, S.; Aboubakar-Souna, D.; Srinivasan, R.; Tamò, M.; Poirié, M.; et al. Proteo-trancriptomic analyses reveal a large expansion of metalloprotease-like proteins in atypical venom Vesicles of the wasp Meteorus pulchricornis (Braconidae). Toxins 2021, 13, 502. [CrossRef]

34. Kazuma, K.; Masuko, K.; Konno, K.; Inagaki, H. Combined venom gland transcriptomic and venom peptidomic analysis of the predatory ant Odontomachus monticola. Toxins 2017, 9, 323. [CrossRef]

35. Tan, J.; Wang, W.; Wu, F.; Li, Y.; Fan, Q. Transcriptome profiling of venom gland from wasp species: De novo assembly, functional annotation, and discovery of molecular markers. BMC Genom. 2020, 21, 1-14. [CrossRef]

36. Aeberhard, J.; Haeberli, G.; Müller, U.; Helbling, A. Specific immunotherapy in hymenoptera venom allergy and concomitant malignancy: A retrospective follow-up focusing on effectiveness and safety. J. Investig. Allergol. Clin. Immunol. 2017, 27, 370-377. [CrossRef]

37. Arias, T.A.; Gómis, V.S.; Mera, T.S.; Castro, A.V.; Gutiérrez, J.V.; Llamazares, A.A.; Amérigo, D.A.; Gonzalez, F.C.; Noche, C.D.; Fernandez, D.G.; et al. Key issues in hymenoptera venom allergy: An update. J. Investig. Allergol. Clin. Immunol. 2017, $27,19-31$. [CrossRef] [PubMed]

38. Baptista-Saidemberg, N.B.; Saidemberg, D.M.; Palma, M.S. Profiling the peptidome of the venom from the social wasp Agelaia pallipes pallipes. J. Proteom. 2011, 74, 2123-2137. [CrossRef] [PubMed]

39. Pucca, M.B.; Cerni, F.A.; Oliveira, I.S.; Jenkins, T.P.; Argemí, L.; Sørensen, C.V.; Ahmadi, S.; Barbosa, J.E.; Laustsen, A.H. Bee updated: Current knowledge on bee venom and bee envenoming therapy. Front. Immunol. 2019, 10, 2090. [CrossRef]

40. Zamith-Miranda, D.; Fox, E.G.P.; Monteiro, A.P.; Gama, D.; Poublan, L.E.; de Araujo, A.F.; Araujo, M.F.C.; Atella, G.C.; Machado, E.A.; Diaz, B.L. The allergic response mediated by fire ant venom proteins. Sci. Rep. 2018, 8, 14427. [CrossRef]

41. El-Wahed, A.A.; Yosri, N.; Sakr, H.; Du, M.; Algethami, A.; Zhao, C.; Abdelazeem, A.; Tahir, H.; Masry, S.; Abdel-Daim, M.; et al. Wasp venom biochemical components and their potential in biological applications and nanotechnological interventions. Toxins 2021, 13, 206. [CrossRef] [PubMed]

42. Cologna, C.T.; dos Santos Cardoso, J.; Jourdan, E.; Degueldre, M.; Upert, G.; Gilles, N.; Uetanabaro, A.P.T.; Costa Neto, E.M.; Thonart, P.; de Pauw, E.; et al. Peptidomic comparison and characterization of the major components of the venom of the giant ant Dinoponera quadriceps collected in four different areas of Brazil. J. Proteom. 2013, 94, 413-422. [CrossRef] [PubMed]

43. Pluzhinikov, K.A.; Nol'de, D.E.; Tertyshnikova, S.M.; Sukhanov, S.V.; Sobol', A.G.; Torgov, M.; Filippov, A.K.; Arsen'ev, A.S.; Grishin, E.V. Structure-activity study of the basic toxic component of venom from the ant Ectatomma tuberculatum. Bioorganicheskaia Khimiia 1994, 20, 857-871.

44. Bordon, K.C.F.; Wiezel, G.A.; Amorim, F.G.; Arantes, E.C. Arthropod venom Hyaluronidases: Biochemical properties and potential applications in medicine and biotechnology. J. Venom. Anim. Toxins Incl. Trop. Dis. 2015, 21, 43. [CrossRef]

45. Silva, M.F.; Mota, C.M.; Miranda, V.D.S.; Cunha, A.D.O.; Silva, M.C.; Naves, K.S.C.; De Oliveira, F.; Silva, D.A.D.O.; Mineo, T.W.P.; Santiago, F.M. Biological and enzymatic characterization of proteases from crude venom of the ant Odontomachus bauri. Toxins 2015, 7, 5114-5128. [CrossRef] [PubMed]

46. Cevallos, M.; Navarro-Duque, C.; Varela-Julia, M.; Alagon, A. Molecular mass determination and assay of venom hyaluronidases by sodium dodecyl sulfate-polyacrylamide gel electrophoresis. Toxicon 1992, 30, 925-930. [CrossRef]

47. Rungsa, P.; Incamnoi, P.; Sukprasert, S.; Uawonggul, N.; Klaynongsruang, S.; Daduang, J.; Patramanon, R.; Roytrakul, S.; Daduang, S. Cloning, structural modelling and characterization of VesT2s, a wasp venom hyaluronidase (HAase) from Vespa tropica. J. Venom. Anim. Toxins Incl. Trop. Dis. 2016, 22, 1-11. [CrossRef]

48. Jacomini, D.L.J.; Pereira, F.D.C.; Pinto, J.R.A.D.S.; dos Santos, L.D.; Neto, A.J.D.S.; Giratto, D.T.; Palma, M.S.; Zollner, R.D.L.; Braga, M.R.B. Hyaluronidase from the venom of the social wasp Polybia paulista (Hymenoptera, Vespidae): Cloning, structural modeling, purification, and immunological analysis. Toxicon 2013, 64, 70-80. [CrossRef] 
49. Wurm, Y.; Wang, J.; Riba-Grognuz, O.; Corona, M.; Nygaard, S.; Hunt, B.; Ingram, K.K.; Falquet, L.; Nipitwattanaphon, M.; Gotzek, D.; et al. The genome of the fire ant Solenopsis invicta. Proc. Natl. Acad. Sci. USA 2011, 108, 5679-5684. [CrossRef]

50. Bonasio, R.; Zhang, G.; Ye, C.; Mutti, N.S.; Fang, X.; Qin, N.; Donahue, G.; Yang, P.; Li, Q.; Li, C.; et al. Genomic comparison of the ants Camponotus floridanus and Harpegnathos saltator. Science 2010, 329, 1068-1071. [CrossRef]

51. Mariano, D.O.C.; de Oliveira, U.C.; Zaharenko, A.J.; Pimenta, D.C.; Rádis-Baptista, G.; Da Silva, P.; Álvaro, R.D.B. Bottom-Up Proteomic Analysis of Polypeptide Venom Components of the Giant Ant Dinoponera Quadriceps. Toxins 2019, 11, 448. [CrossRef]

52. Dos Santos Pinto, J.R.; Fox, E.G.P.; Saidemberg, D.M.; Santos, L.D.; Menegasso, A.R.D.S.; Costa-Manso, E.; Machado, E.A.; Bueno, O.C.; Palma, M.S. Proteomic view of the venom from the fire ant Solenopsis invicta Buren. J. Proteome Res. 2012, 11, $4643-4653$. [CrossRef] [PubMed]

53. Dos Santos Pinto, J.R.; Games, P.D.; Azevedo, D.O.; Barros, E.; De Oliveira, L.L.; Ramos, H.J.D.O.; Baracat-Pereira, M.C.; Serrão, J.E. Proteomic analysis of the venom of the predatory ant Pachycondyla striata (Hymenoptera: Formicidae). Arch. Insect Biochem. Physiol. 2017, 96, e21424. [CrossRef]

54. Schmidt, J.O.; Blum, M.S.; Overal, W.L. Comparative enzymology of venoms from stinging Hymenoptera. Toxicon 1986, 24, 907-921. [CrossRef]

55. Bordon, K.; Perino, M.G.; Giglio, J.R.; Arantes, E.C. Isolation, enzymatic characterization and antiedematogenic activity of the first reported rattlesnake hyaluronidase from Crotalus durissus terrificus venom. Biochimie 2012, 94, 2740-2748. [CrossRef]

56. Peiren, N.; de Graaf, D.C.; Vanrobaeys, F.; Danneels, E.L.; Devreese, B.; Van Beeumen, J.; Jacobs, F.J. Proteomic analysis of the honey bee worker venom gland focusing on the mechanisms of protection against tissue damage. Toxicon 2008, 52, 72-83. [CrossRef] [PubMed]

57. Wu, C.-Y.; Huang, J.-M.; Zhao, Y.-J.; Xu, Z.-W.; Zhu, J.-Y. Venom serine proteinase homolog of the ectoparasitoid Scleroderma guani impairs host phenoloxidase cascade. Toxicon 2020, 183, 29-35. [CrossRef]

58. Hoffman, D.R. Hymenoptera Venom Allergens. Clin. Rev. Allergy Immunol. 2006, 30, 109-128. [CrossRef]

59. Winningham, K.M.; Fitch, C.D.; Schmidt, M.; Hoffman, D.R. Hymenoptera venom protease allergens. J. Allergy Clin. Immunol. 2004, 114, 928-933. [CrossRef]

60. Whitworth, S.T.; Blum, M.S.; Travis, J. Proteolytic Enzymes from Larvae of the Fire Ant, Solenopsis invicta. J. Biol. Chem. 1998, 273, 14430-14434. [CrossRef]

61. Zóia, M.A.P.; Azevedo, F.V.P.D.V.; Vecchi, L.; Mota, S.T.S.; Rodovalho, V.; Cordeiro, A.O.; Correia, L.I.V.; Silva, A.C.A.; Ávila, V.D.; De Araújo, T.G.; et al. Inhibition of triple-negative breast cancer cell aggressiveness by cathepsin D blockage: Role of Annexin A1. Int. J. Mol. Sci. 2019, 20, 1337. [CrossRef]

62. Valentin, E.; Ghomashchi, F.; Gelb, M.H.; Lazdunski, M.; Lambeau, G. Novel Human Secreted Phospholipase A2 with Homology to the Group III Bee Venom Enzyme. J. Biol. Chem. 2000, 275, 7492-7496. [CrossRef]

63. Von Sicard, N.; Candy, D.; Anderson, M. The biochemical composition of venom from the pavement ant (Tetramorium caespitum L.). Toxicon 1989, 27, 1127-1133. [CrossRef]

64. Nidamarthi, H.V.K.; Choudhury, M.; Velmurugan, D. Understanding the binding mechanism of succinic acid against phospholipase A 2 from bee venom. J. Biochem. Mol. Toxicol. 2021, 35, e22715. [CrossRef]

65. Nakashima, A.; Tomono, S.; Yamazaki, T.; Inui, M.; Morita, N.; Ichimonji, I.; Takagi, H.; Nagaoka, F.; Matsumoto, M.; Ito, Y.; et al. Phospholipase A2 from bee venom increases poly(I:C)-induced activation in human keratinocytes. Int. Immunol. 2020, 32, 371-383. [CrossRef] [PubMed]

66. Komi, D.E.A.; Shafaghat, F.; Zwiener, R. Immunology of Bee Venom. Clin. Rev. Allergy Immunol. 2018, 54, 386-396. [CrossRef]

67. Bourgeois, E.A.; Subramaniam, S.; Cheng, T.-Y.; de Jong, A.; Layre, E.; Ly, D.; Salimi, M.; Legaspi, A.; Modlin, R.L.; Salio, M.; et al. Bee venom processes human skin lipids for presentation by CD1a. J. Exp. Med. 2015, 212, 149-163. [CrossRef] [PubMed]

68. Sukprasert, S.; Rungsa, P.; Uawonggul, N.; Incamnoi, P.; Thammasirirak, S.; Daduang, J.; Daduang, S. Purification and structural characterisation of phospholipase A1 (Vespapase, Ves a 1) from Thai banded tiger wasp (Vespa affinis) venom. Toxicon 2013, 61, 151-164. [CrossRef]

69. Hoffman, D.R.; Sakell, R.H.; Schmidt, M. Sol i 1, the phospholipase allergen of imported fire ant venom. J. Allergy Clin. Immunol. 2005, 115, 611-616. [CrossRef]

70. Nikodijević, D.D.; Jovankić, J.V.; Cvetković, D.M.; Anđelković, M.Z.; Nikezić, A.G.; Milutinović, M.G. L-amino acid oxidase from snake venom: Biotransformation and induction of apoptosis in human colon cancer cells. Eur. J. Pharmacol. 2021, $910,174466$. [CrossRef] [PubMed]

71. De Oliveira, I.S.; Cardoso, I.A.; Bordon, K.D.C.F.; Carone, S.E.I.; Boldrini-França, J.; Pucca, M.B.; Zoccal, K.F.; Faccioli, L.H.; Sampaio, S.V.; Rosa, J.C.; et al. Global proteomic and functional analysis of Crotalus durissus collilineatus individual venom variation and its impact on envenoming. J. Proteom. 2019, 191, 153-165. [CrossRef] [PubMed]

72. Kasai, K.; Ishikawa, T.; Nakamura, T.; Miura, T. Antibacterial properties of 1-amino acid oxidase: Mechanisms of action and perspectives for therapeutic applications. Appl. Microbiol. Biotechnol. 2015, 99, 7847-7857. [CrossRef]

73. Izidoro, L.F.M.; Sobrinho, J.C.; Mendes, M.M.; Costa, T.R.; Grabner, A.N.; Rodrigues, V.D.M.; Da Silva, S.L.; Zanchi, F.B.; Zuliani, J.P.; Fernandes, C.F.; et al. Snake venom L-amino acid oxidases: Trends in pharmacology and biochemistry. BioMed Res. Int. 2014, 2014, 196754. [CrossRef] [PubMed] 
74. Perumal Samy, R.; Gopalakrishnakone, P.; Thwin, M.M.; Chow, T.K.V.; Bow, H.; Yap, E.H.; Thong, T.W.J. Antibacterial activity of snake, scorpion and bee venoms: A comparison with purified venom phospholipase A2 enzymes. J. Appl. Microbiol. 2007, 102, 650-659. [CrossRef] [PubMed]

75. Wang, W.-J. Acurhagin-C, an ECD disintegrin, inhibits integrin $\alpha \mathrm{v} \beta 3$-mediated human endothelial cell functions by inducing apoptosis via caspase-3 activation. Br. J. Pharmacol. 2010, 160, 1338-1351. [CrossRef]

76. Yeh, C.H.; Peng, H.C.; Huang, T.F. Accutin, a new disintegrin, inhibits angiogenesis in vitro and in vivo by acting as integrin alphavbeta3 antagonist and inducing apoptosis. Blood 1998, 92, 3268-3276. [CrossRef]

77. Sachetto, A.T.A.; Mackman, N. Modulation of the mammalian coagulation system by venoms and other proteins from snakes, arthropods, nematodes and insects. Thromb. Res. 2019, 178, 145-154. [CrossRef]

78. Bade, B.C.; Cruz, C.S.D. Lung Cancer. Clin. Chest Med. 2020, 41, 1-24. [CrossRef] [PubMed]

79. Jones, G.S.; Baldwin, D.R. Recent advances in the management of lung cancer. Clin. Med. 2018, 18, s41-s46. [CrossRef]

80. Badr, G.; Garraud, O.; Daghestani, M.; Al-Khalifa, M.S.; Richard, Y. Human breast carcinoma cells are induced to apoptosis by samsum ant venom through an IGF-1-dependant pathway, PI3K/AKT and ERK signaling. Cell. Immunol. 2012, $273,10-16$. [CrossRef] [PubMed]

81. Taslimi, Y.; Zahedifard, F.; Rafati, S. Leishmaniasis and various immunotherapeutic approaches. Parasitolology 2018, 145, 497-507. [CrossRef]

82. Akhoundi, M.; Downing, T.; Votypka, J.; Kuhls, K.; Lukeš, J.; Cannet, A.; Ravel, C.; Marty, P.; Delaunay, P.; Kasbari, M.; et al. Leishmania infections: Molecular targets and diagnosis. Mol. Asp. Med. 2017, 57, 1-29. [CrossRef]

83. Laemmli, U.K. Cleavage of Structural Proteins during the assembly of the head of bacteriophage T4. Nature 1970, 227, 680-685 [CrossRef]

84. Rodrigues, V.M.; Soares, A.; Guerra-Sá, R.; Rodrigues, V.; Fontes, M.; Giglio, J.R. Structural and functional characterization of neuwiedase, a nonhemorrhagic fibrin(ogen)olytic metalloprotease from Bothrops neuwiedi snake venom. Arch. Biochem. Biophys. 2000, 381, 213-224. [CrossRef]

85. Di Ferrante, N. Turbidimetric measurement of acid mucopoly-saccharides and hyaluronidase activity. J. Biol. Chem. 1956, 220, 303-306. [CrossRef]

86. De Haas, G.; Postema, N.; Nieuwenhuizen, W.; van Deenen, L. Purification and properties of phospholipase a from porcine pancreas. Biochim. Biophys. Acta (BBA) Enzym. 1968, 159, 103-117. [CrossRef]

87. Schröder, E.; Lübke, K.; Lehmann, M.; Beetz, I. Haemolytic activity and action on the surface tension of aqueous solutions of synthetic melittins and their derivatives. Experientia 1971, 27, 764-765. [CrossRef] [PubMed]

88. Tan, N.-H.; Ponnudurai, G. An investigation on the antigenic cross-reactivity of Calloselasma rhodostoma (Malayan pit viper) venom hemorrhagin, thrombin-like enzyme and l-amino acid oxidase using enzyme-linked immunosorbent assay. Toxicon 1994, 32, 1265-1269. [CrossRef]

89. Assakura, M.T.; Salomão, M.D.G.; Puorto, G.; Mandelbaum, F.R. Hemorrhagic, fibrinogenolytic and edema-forming activities of the venom of the colubrid snake Philodryas olfersii (green snake). Toxicon 1992, 30, 427-438. [CrossRef]

90. Mosmann, T. Rapid colorimetric assay for cellular growth and survival: Application to proliferation and cytotoxicity assays. $J$ Immunol. Methods 1983, 65, 55-63. [CrossRef] 